\title{
nombalina
}

(8)

\section{As Guerras Púnicas}

Autor(es): $\quad$ Monteiro, João Gouveia

Publicado por: Imprensa da Universidade de Coimbra

URL persistente:

URI:http://hdl.handle.net/10316.2/36915

DOI:

DOI:http://dx.doi.org/10.14195/978-989-26-0954-6_6.1

Accessed : $\quad$ 26-Apr-2023 03:43:08

A navegação consulta e descarregamento dos títulos inseridos nas Bibliotecas Digitais UC Digitalis, UC Pombalina e UC Impactum, pressupõem a aceitação plena e sem reservas dos Termos e Condições de Uso destas Bibliotecas Digitais, disponíveis em https://digitalis.uc.pt/pt-pt/termos.

Conforme exposto nos referidos Termos e Condições de Uso, o descarregamento de títulos de acesso restrito requer uma licença válida de autorização devendo o utilizador aceder ao(s) documento(s) a partir de um endereço de IP da instituição detentora da supramencionada licença.

Ao utilizador é apenas permitido o descarregamento para uso pessoal, pelo que o emprego do(s) título(s) descarregado(s) para outro fim, designadamente comercial, carece de autorização do respetivo autor ou editor da obra.

Na medida em que todas as obras da UC Digitalis se encontram protegidas pelo Código do Direito de Autor e Direitos Conexos e demais legislação aplicável, toda a cópia, parcial ou total, deste documento, nos casos em que é legalmente admitida, deverá conter ou fazer-se acompanhar por este aviso. 
JOSÉ LUÍS BRANDÃO FRANCISCO DE OLIVEIRA (COORD.)

IMPRENSA DA

UNIVERSIDADE

DE COIMBRA

COIMBRA

UNIVERSITY

PRESS
HISTÓRIA DE
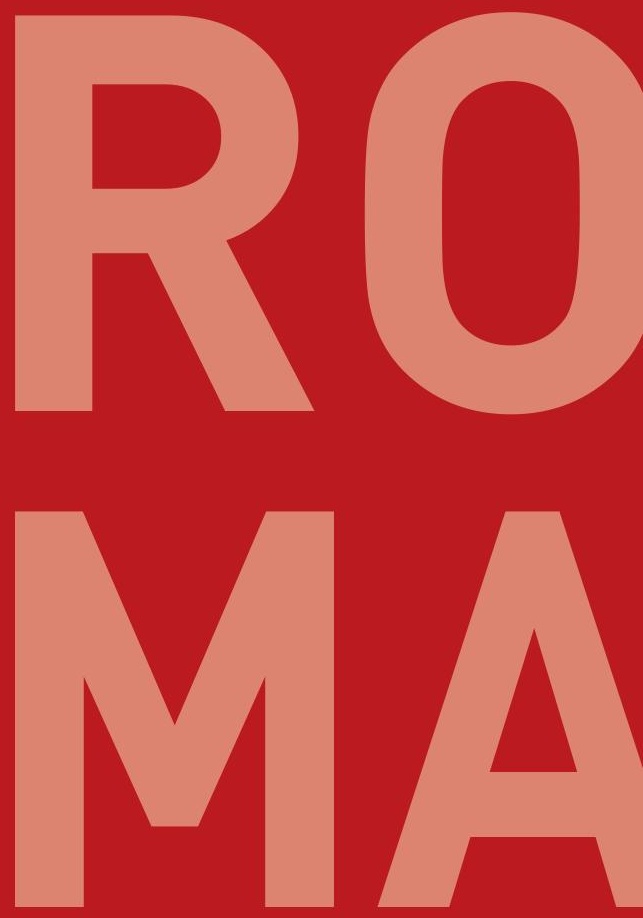

ANTIGA

VOLUME I

DAS ORIGENS À

MORTE DE CÉSAR 


\section{EXPANS ÃO NOMEDITERRÂNEO}

\subsection{AS GUERRAS PÚNICAS}

João Gouveia Monteiro Faculdade de Letras da Universidade de Coimbra, Centro de História da Sociedade e da Cultura

Sumário. Incidentes ocorridos em Siracusa (na Sicília) em 264 a. C. que levaram ao primeiro conflito de Roma fora da península itálica: uma guerra feroz pelo domínio do Mediterrâneo, entre Roma e Cartago, as duas maiores potências da região. As três fases das Guerras Púnicas, que se prolongariam até 146 a. C., a terminar na vitória absoluta de Roma e a destruição - física e política do Estado de Cartago. A influência destes 120 anos na história futura de Roma (e da própria Europa).

\section{O cenário}

As "Guerras Púnicas" opuseram Roma a Cartago (cidade do Norte de África fundada por fenícios, a quem os Romanos chamavam Poeni) e configuraram uma disputa cerrada pelo domínio do Mediterrâneo. Geralmente, divide-se este confronto - um dos mais prolongados do mundo antigo em três etapas: a Primeira Guerra Púnica sucedeu entre 264 e 241 a. C. e 
centrou-se sobretudo na Sicília; a Segunda Guerra Púnica - a mais espetacular de todas, associada à figura do lendário general cartaginês Aníbal Barca - decorreu entre 218 e 201 a. C. e a Itália foi o seu palco principal; por fim, a Terceira Guerra Púnica circunscreveu-se a uma pequena região do Norte de África, tendo demorado apenas três anos - de 149 a 146 a. C.

As Guerras Púnicas constituem um marco importantíssimo na história de Roma. Em 264 a. C., no início do conflito, Roma era uma potência exclusivamente itálica, mas 118 anos mais tarde tinha-se guindado a uma posição de domínio de toda a bacia do Mediterrâneo e avançava a passos largos para a criação de um império. Se Cartago tivesse triunfado, a história de Roma teria sido completamente diferente, e, muito provavelmente, a Europa em que hoje vivemos seria - ao nível da sua cultura, da sua língua, da sua tradição jurídica ou mesmo da sua religião - bem distinta.

Ao despertar nos Romanos a consciência do seu imenso potencial, as Guerras Púnicas incitaram-nos também a escrever a sua própria história; por isso, este é um dos conflitos mais bem documentados do mundo antigo. Todavia, os relatos que subsistiram até aos nossos dias são exclusivamente gregos ou romanos, não havendo nenhuma narrativa que nos forneça o ponto de vista cartaginês dos acontecimentos.

A fonte mais importante é a "História" de Políbio (c. 203-c. 120 a. C.), um grego que combateu contra Roma durante a Terceira Guerra Macedónica; tendo sido feito prisioneiro, Políbio foi um dos reféns enviados para Roma, em 167 a. C.; aqui, tornou-se íntimo de Cipião Emiliano, que acompanhou nas campanhas de África, da Hispânia e do Mediterrâneo Ocidental. A "História" de Políbio, de que sobreviveu apenas uma parte (até à batalha de Canas, em 216 a. C., com alguns fragmentos posteriores) visa explicar ao público de língua grega como é que Roma tinha conseguido dominar o Mediterrâneo; para escrever esta obra, bastante sóbria e analítica, o autor, que nutria grande admiração pelo povo romano, serviu-se de documentação variada, para além de ter podido falar com muitos participantes diretos na guerra contra Aníbal Barca.

Já Tito Lívio (59 a. C.-17 d. C.) escreveu a sua "História de Roma" muito mais tarde, com intenso sentido patriótico; a sua obra, de cunho mais dramático e sem a mesma exigência com as fontes, nem a mesma 
qualidade de informação técnica (Lívio não possuía a experiência militar de Políbio), também não nos chegou completa; porém, tem a vantagem de nos oferecer o relato mais longo da guerra contra Aníbal, até porque Tito Lívio teve acesso à obra completa de Políbio.

Para a Terceira Guerra Púnica, que não está coberta pelos relatos disponíveis de Políbio ou de Lívio, a fonte principal é Apiano (c. 95-c. 170 d. C.), um autor de origem grega, que escreveu em Roma na época do imperador Antonino Pio; a sua "História Romana", organizada em 24 livros, parece ter-se baseado na narrativa perdida de Políbio.

Outras fontes, menos relevantes para o nosso propósito, são Díon Cássio (c. 163-235 d. C., um senador romano da região oriental da Grécia, que escreveu uma "História de Roma", parcialmente perdida, que se prolonga até à época em que viveu), Plutarco (c. 46-120 d. C., escritor grego e autor das célebres "Vidas Paralelas") e Cornélio Nepos (um autor de finais do séc. I a. C., que escreveu umas breves biografias de Amílcar Barca e do seu filho Aníbal).

Tanto quanto se sabe, foram alguns fenícios oriundos da cidade de Tiro (no atual Líbano) que, nos finais do séc. VIII a. C., fundaram a urbe de Cartago. Graças ao seu talento comercial, nos séculos seguintes a comunidade cartaginesa prosperou, em ambiente de concorrência com as colónias gregas, que iam surgindo um pouco por toda a parte (na Sicília, no sul de Itália, nas costas da Hispânia ou no sul da Gália). Na Sićlia, Cartagineses e Gregos conheceram sucessos alternados, que ajudam a explicar a repartição de áreas de influência na ilha e a afirmação de capitães mercenários, ou de "tiranos" como Dionísio ou Agátocles.

A partir do séc. V a. C., o poderio dos Púnicos aumentou também em África, graças ao facto de Cartago ter deixado de pagar subsídios aos governantes líbios, ao controlo das urbes fenícias da área (como Útica ou Adrumeto), à realização de viagens de exploração ao longo da costa norte-africana, à travessia do estreito de Gibraltar e à implantação de novas feitorias. Com estes feitos, e ainda com o desenvolvimento de colonatos no sul da Hispânia, a cidade de Cartago conquistou posições costeiras cruciais, assegurou o domínio de bons portos e construiu uma armada poderosa, por meio da qual começou a controlar as principais rotas comerciais de acesso ao Mediterrâneo ocidental. 
A riqueza de Cartago não assentava, porém, apenas no comércio: tinha uma forte base agrícola, resultado da exploração dos férteis terrenos norte-africanos, que ajudavam à prosperidade de uma aristocracia fundiária, enriquecida com o cultivo de muitos cereais, de uvas, de figos, de azeitonas, de amêndoas e de romãs, em quantidades que permitiam a obtenção de excedentes destinados à exportação.

Por volta do ano 300 a. C., estima-se que Cartago controlasse já metade do atual território da Tunísia, ou seja, aproximadamente a mesma superfície territorial que Roma e os seus aliados dominavam (embora as terras sob o domínio púnico possuíssem um índice de produtividade mais elevado). Ao contrário dos Romanos, os Cartagineses não tinham por hábito estender a cidadania e os direitos políticos aos povos das áreas que ficavam sob o seu controlo; por isso, em Cartago, a guerra era sobretudo praticada por mercenários contratados pelo Estado, e não pelos seus abastados cidadãos.

Pensa-se que, inicialmente, Cartago terá sido uma monarquia de pendor religioso, mas sabemos que, no séc. III a. C., tinha já lugar a eleição anual de dois "sufetas", que eram os principais funcionários executivos do Estado e que possuíam o poder civil e religioso, embora não detivessem o comando militar. Um Conselho de 30 anciãos (ou "Gerúsia"), com funções de assessoria e talvez extraído do "Conselho dos 104", que o supervisionava, assim como uma Assembleia do Povo (dominada por um número restrito de famílias nobres) completavam o sistema político cartaginês, a quem os historiadores reconhecem hoje um equilíbrio interessante entre "monarquia" (sufetas), "aristocracia" (Conselho dos 104) e "democracia” (Assembleia do Povo). Certo é que, na década de 280 a. C., Cartago se impunha como uma cidade riquíssima, controlando o comércio no Mediterrâneo ocidental e dominando as costas de África e da Hispânia, assim como as ilhas da Sicília, da Sardenha e da Córsega, entre outras.

Quanto a Roma, como foi explicado nos capítulos anteriores, debelara na segunda metade do séc. IV a. C. a última grande rebelião das outras urbes latinas, pusera fim à Liga Latina ${ }^{1}$ e estendera amplamente a cidadania

\footnotetext{
1 Vide atrás De Man, cap. 5.2 §2.
} 
romana - gerando cidades aliadas, que perdiam independência política, mas que obtinham grandes benefícios e que continuavam a poder gerir os seus assuntos internos. Até inícios do séc. III a. C., a expansão romana conheceu um ímpeto assinalável, devido também à submissão das colónias gregas da Itália peninsular. Os recursos humanos da República e a capacidade integradora de Roma potenciavam um crescimento assinalável da escala da guerra e pareciam anunciar que, em breve, a cidade deixaria de ser uma potência meramente peninsular. O conflito com Cartago tornava-se iminente, e nada mais lógico do que ser a ilha da Sicília - situada entre as duas potências rivais e um território estratégico para o controlo do comércio mediterrânico - a constituir o palco dos primeiros confrontos.

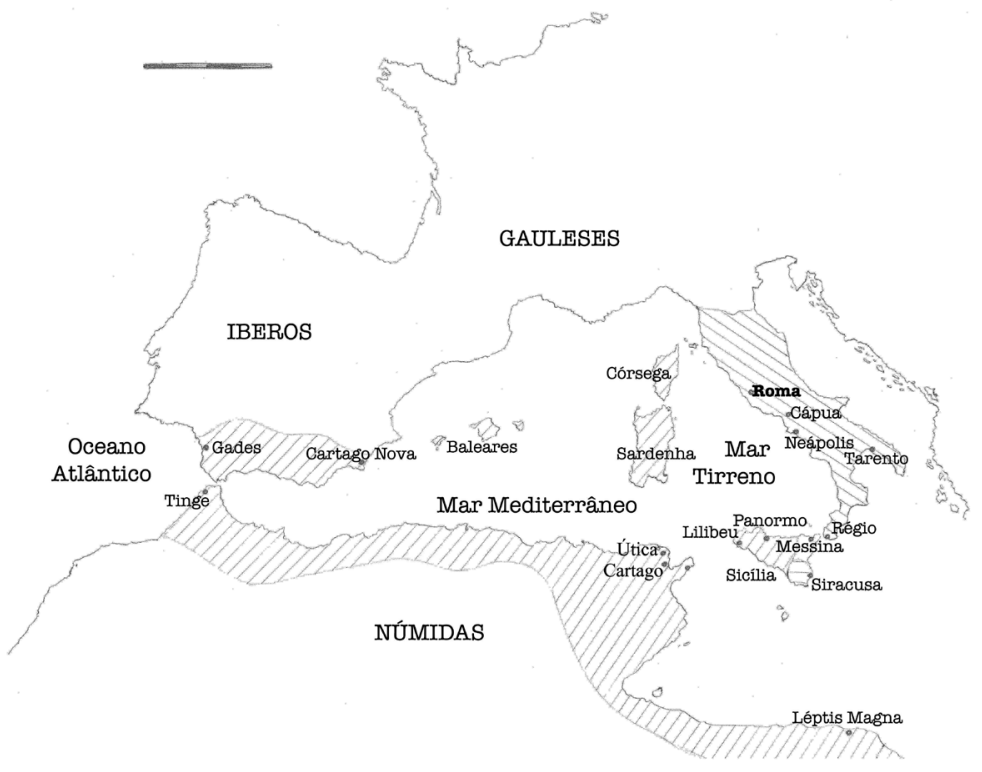

Fig. 1. Guerras Púnicas - por Fábio Mordomo

\section{A Primeira Guerra Púnica (264-241 a. C.)}

Em 289 a. C., a morte de Agátocles, o tirano grego de Siracusa (a principal cidade do sudeste da Sicília), abriu uma crise política na ilha. Agátocles conquistara Siracusa entre 315 e 312 a. C. e, para afirmar o seu poder, 
para conseguir enfrentar os Cartagineses - que dominavam as partes sul e ocidental da Sicília - e para alargar o domínio da sua cidade, apoiara-se em forças mercenárias. Entre estas, contava-se um bando de soldados da Campânia, descendentes das tribos montanhesas que, nos finais do séc. V a. C., se tinham estabelecido nas planícies desta fértil região do sul da Itália.

À morte de Agátocles, os mercenários da Campânia, desmobilizados, deslocaram-se para Messina, a principal urbe do nordeste da Sicília, que os acolheu, mas eles começaram a provocar danos, massacrando cidadãos, raptando mulheres, roubando diversos bens e utilizando a cidade como base para incursões contra alguns territórios vizinhos, aos quais iam impondo tributos e outros encargos. Por esta altura, os mercenários da Campânia terão começado a designar-se a si próprios por "mamertinos" (mamertini), ou seja, "filhos de Marte", o deus romano da guerra.

Pouco tempo depois (em 280 a. C.), Roma iniciava a sua guerra contra Pirro, o rei grego do Epiro (atual Albânia), que tinha sido contratado por uma cidade grega da Calábria, Tarento, para combater os Romanos e as suas intenções de domínio do sul da Itália. A guerra contra Pirro, que se prolongou até 275 a. C. (data da vitória final dos Romanos, arrancada a ferros na batalha de Malvento), obrigou Roma a acautelar a proteção de algumas cidades suas aliadas ${ }^{2}$. Uma dessas cidades foi Régio, localizada no lado oriental do estreito de Messina, onde os Romanos instalaram uma guarnição de 4000 homens, chefiada por um oficial chamado Décio. Esta força era composta sobretudo por soldados da Campânia, facto que contribuiu para a sua revolta, em jeito de imitação dos seus parentes e vizinhos de Messina... Os homens de Décio logo começaram a maltratar os cidadãos de Régio, e Roma, absorvida pelo esforço da guerra contra Pirro e a cidade de Tarento, não teve condições para responder de pronto a este ato de traição.

Em 276 a. C., Pirro, animado pelos seus sucessos iniciais na guerra contra os Romanos (vitórias na batalha do rio Síris, em 280, e na batalha de Ásculo, em 279), tentou a sua sorte na Sicília, correspondendo a um apelo de Siracusa para que defendesse as cidades gregas da ilha.

\footnotetext{
2 Vide De Man, cap. $5.2 \S 5$.
} 
Apesar de espetacular, a investida do rei epirota acabou em fiasco, com uma derrota naval frente à poderosa frota de Cartago. No ano seguinte, Roma derrotou Pirro em Malvento e, três anos mais tarde (em 272 a. C.), Tarento caiu também nas suas mãos, confirmando o domínio romano sobre o sul de Itália. Assim, em 271 a. C., os Romanos puderam finalmente ocupar-se de Régio, cidade que conquistaram depois de um longo cerco; a vingança foi cruel e os 300 soldados campanos capturados com vida foram executados no Forum de Roma.

Enquanto isso, na Sicília - território ainda estranho aos Romanos -, a situação dos mamertinos ia-se tornando cada vez mais difícil. Tanto mais que, em Siracusa, havia agora um novo líder, eleito pelo exército: Hierão, um soldado grego, experiente nas guerras contra as incursões italianas e um bom político, que casara com a filha de um dos notáveis da cidade. À frente do exército de Siracusa, Hierão venceu os mamertinos em duas batalhas travadas em data incerta, entre 271 e 265 a. C., primeiro junto ao rio Ciamosoro e, depois, de forma mais categórica, perto do rio Longano.

Neste contexto, em 265 a. C., os mercenários da Campânia em Messina pediram ajuda a Cartago e a Roma. Bem implantada no sul e na parte ocidental da Sicília, Cartago acorreu rapidamente, através de um oficial chamado Aníbal, que comandava a esquadra púnica ao largo das ilhas Líparis (a nordeste da Sicília). Aparentemente, os Cartagineses terão tentado ganhar algum tempo na sua posição perante Hierão, ao mesmo tempo que tentavam uma aliança com os mamertinos, o que lhes permitiu ocupar uma parte da cidade de Messina; perante isto, Hierão, indisponível para fazer a guerra contra Cartago, retirou para Siracusa. Quanto aos Romanos, parece que o senado hesitou na posição a tomar: recusar a aliança com os mamertinos, apoiantes recentes do traidor Décio e dos rebeldes de Régio? Ou avançar para essa estranha aliança, tendo em conta o interesse em defender a supremacia de Roma no sul de Itália, tanto mais que se tratava de uma região de conquista recente e precária, devido às ligações entre as cidades helenísticas da Calábria e as comunidades gregas do sul da Sicília?...

Perante a hesitação do senado, foram os cônsules eleitos em 264 (Ápio Cláudio Cáudice e Marco Fúlvio Flaco) que persuadiram o povo, nos 
Comitia Centuriata, a pronunciar-se a favor de uma expedição siciliana; a perspetiva de bons despojos deve ter atraído os cidadãos mais ricos e decidiu a votação. Deste modo, Ápio Cláudio tornou-se o primeiro líder romano a atravessar o mar com um exército (o outro cônsul ficou na Etrúria, vigiando os Volsínios). Provavelmente, os Romanos esperariam um confronto relativamente fácil com Hierão de Siracusa, e não propriamente uma guerra contra Cartago, assunto que a assembleia não deve sequer ter votado. No fundo, como lembra Políbio, tratava-se de aproveitar uma boa oportunidade, juntando uma campanha lucrativa e prestigiante ao interesse subliminar (realçado por Díon Cássio) de travar Cartago, que após a queda de Tarento estava praticamente face a face com Roma.

Em 264 (ou 263) a. C., os mamertinos expulsaram a pequena guarnição cartaginesa de Messina, e o tribuno Gaio Cláudio atravessou o estreito por duas vezes, durante a noite, para entabular negociações. Concretizada a aliança entre os Romanos e os mercenários, o cônsul Ápio Cláudio avançaria mais tarde, também de noite, para iludir a vigilância marítima da frota cartaginesa. Ao mesmo tempo, Roma enviou embaixadores a Siracusa e a Cartago, justificando a sua decisão de apoiar os mamertinos (em 279-278 a. C., Roma e Cartago haviam assinado um tratado de apoio mútuo contra o rei Pirro, onde se regulavam as esferas de influência das duas potências e se prometia o desenvolvimento de relações amistosas entre ambas...).

Em resposta, Cartago e Hierão uniram-se para conquistar Messina e travar os Romanos. O líder de Siracusa cercou a cidade, mas o assédio fracassou, graças a um ataque bem-sucedido de Cláudio ao acampamento grego e a uma vitória romana numa escaramuça contra os Púnicos; com isto, a aliança contra Roma desfez-se. Pouco depois, Cláudio devastou os arredores de Siracusa, regressando depois a Roma.

Os cônsules eleitos para 263 (Mânio Valério Máximo e Mânio Otacílio Crasso) avançaram então para a Sicília, cada qual à frente de duas legiões e de duas "alas" de tropas auxiliares (ao todo, seriam cerca de 40000 soldados). Os sucessos romanos não se fizeram esperar, e Valério Máximo acabou por vencer Hierão, que se rendeu e se tornou aliado de Roma. Este facto seria decisivo para a vitória romana, devido às dificuldades de abastecimento de que o exército já sofria, em resultado do bloqueio 
do estreito de Messina pelos Cartagineses. Hierão continuou à frente da cidade de Siracusa e, até ao final dos seus dias, permaneceria leal a Roma. Segundo Diodoro Sículo, na sequência dos acontecimentos de 263 a. C., 67 cidades sicilianas passaram-se para os Romanos. Roma entrara com o pé direito na guerra e, em perto de dois anos, conseguira garantir uma posição fortíssima na ilha até então dominada por Gregos e Púnicos!

Do outro lado, Cartago, cuja presença na Sicília era já secular e que há muito se esforçava por dominar toda a ilha, via-se agora confrontada com um novo desafio. Porém, confiantes na sua experiência e no seu poderio naval, os Púnicos contavam vencer Roma nesta primeira disputa direta entre as duas potências e não terão sequer sonhado com uma guerra tão arrastada e tão renhida quanto aquela que veio a acontecer.

O primeiro episódio militar relevante da Primeira Guerra Púnica, após a aliança entre Roma e Hierão de Siracusa, foi a disputa pela cidade de Agrigento, situada a meio da costa sul da Sicília (isto é, bem frente a África) e que Cartago queria utilizar como sua base principal. No verão de 262, os Romanos (através dos cônsules Lúcio Postúmio Megelo e Quinto Manúlio Vítulo) cercaram Agrigento, defendida pelo general cartaginês Gisgão, à frente de uma pequena guarnição armada e de uma massa de habitantes e refugiados, que atingiria as 50000 almas. O bloqueio romano, facilitado pelo facto de Agrigento não possuir um porto (ficava situada a alguns quilómetros da costa, num planalto), implicou a instalação de dois acampamentos fortificados, a construção de fossos e de fortins e o levantamento de uma linha de circunvalação e de outra de contravalação, para impedir o acesso à cidade. Os Cartagineses resistiram como puderam, através de surtidas e beneficiando de um socorro que lhes chegou por meio de Hanão, graças ao qual conseguiram atacar o abastecimento romano e cortar as linhas de comunicação adversárias. Durante algum tempo, Romanos e Cartagineses mantiveram-se acampados a cerca de $2 \mathrm{~km}$ de distância, com os Púnicos a resistirem à ideia de travar uma batalha decisiva. No entanto, a situação dentro da cidade tornou-se de tal forma desesperada que Hanão foi forçado a combater: a vitória sorriu aos Romanos e, assim, sete meses depois do início do cerco, ou seja, já em 261 a. C., Agrigento capitulou. 
Esta importante vitória romana (que não teria sido possível sem o bom aprovisionamento garantido pela aliança com Hierão de Siracusa) animou o senado a avançar para a tentativa de expulsão dos Cartagineses da Sicília. A guerra ganhava, pois, uma nova dimensão! Ciente de que não poderia alcançar o seu objetivo sem conquistar vantagem nos mares, o senado romano tomou então uma decisão relevante: decidiu construir uma esquadra de guerra, que seria composta por cem embarcações "quinquerremes" (isto é, próprias para grupos-base de cinco remadores) e vinte "trirremes" (pensadas para grupos-base de três remadores). Os antecedentes romanos na guerra naval eram pouco expressivos, pelo que se optou por copiar um modelo de "cinco" (ou quinquerreme) cartaginês capturado perto de Régio. Em cerca de dois meses, a esquadra ficou pronta, tendo-se recrutado e treinado perto de 30000 remadores (os "cincos" levavam 300 homens, dos quais 20 marinheiros, e os "três" levavam 200 homens, entre eles 30 marinheiros, oficiais e soldados) no seio dos cidadãos pobres, dos aliados navais e de outros povos itálicos. Quando se iniciou o ano de 260 a. C., Roma estava apta a manobrar nos mares que envolvem a Sićlia, com os navios equipados com robustos esporões para perfurar os cascos dos barcos adversários e as tripulações habilitadas a executar as manobras de abalroamento e de abordagem então praticadas.

Assim, enquanto o cônsul Gaio Duílio ficava ao comando das forças terrestres na Sicília, o outro magistrado eleito em 260, Gneu Cornélio Cipião, zarpou para a ilha à frente dos primeiros 17 navios. Chegado a Messina, preparou a logística para a restante armada, mas não evitou cair numa cilada naval em Lípara (ilhas Líparis), o que lhe valeu um dissabor e a alcunha de Cipião "Asina" ("burra"). Com o colega aprisionado, Duílio assumiu, em Messina, o comando da jovem armada. Terá sido por esta altura que os Romanos introduziram nas suas embarcações uma importante inovação, o chamado "corvo", que lhes seria muito útil nos primeiros combates navais: trata-se de uma ponte para abordagem com cerca de onze metros de comprimento e um pouco mais de um metro de largura, munida de parapeitos laterais, a qual encaixava num mastro de cerca de sete metros instalado no convés; a ponte era içada ou rebaixada através de um sistema de roldanas, e o nome "corvo" advém do 
facto de a extremidade posterior do pontão estar equipada, na parte de baixo, com um poderoso espigão em forma de bico; o engenhoso sistema permitia girar a ponte de acordo com a direção do ataque do inimigo e possibilitava ao "corvo" ferrar o convés da embarcação adversária; depois, bastava aos soldados romanos atravessarem a ponte e invadirem a embarcação adversária, tirando partido da sua maior capacidade no combate corpo a corpo.

Graças a este dispositivo, Duílio tornou-se o primeiro general romano a vencer os Cartagineses no mar: foi na batalha naval travada em 260 a. C., ao largo de Milas, junto às ilhas Líparis, na costa nordeste da Sicília. Os Púnicos, liderados por Aníbal, tentaram evitar os "corvos", flanqueando a linha romana e atacando pela popa, mas a esquadra latina manobrou a preceito e conseguiu vencer; os Cartagineses perderam 40 a 50 navios, e Duílio pôde comemorar o primeiro triunfo naval romano.

Seguiram-se combates na Córsega, na Sardenha e na Sicília, durante o consulado de Lúcio Cornélio Cipião e de Gaio Aquínio Floro, em 259 a. C. Neste ano, Lúcio Cipião ocupou a Córsega, dando início a um domínio romano, que se prolongaria por vários séculos. No ano seguinte, os Romanos venceram um combate naval perto de Sulci, mas mais relevante e renhida foi a batalha naval travada ao largo de Tíndaris (perto de Milas), em 257 a. C. Neste confronto, algo fortuito, o cônsul Gaio Atílio Régulo venceu com dificuldade, tendo visto nove dos seus navios abalroados e afundados, contra dez navios púnicos capturados e oito afundados.

Em 256 a. C., Roma decidiu mudar de estratégia e invadir a África cartaginesa. Os dois cônsules desse ano, Mânlio Vulsão Longo e Marco Atílio Régulo, partiram do cabo Paquino (no extremo sudeste da Sicília) com uma imensa esquadra de 330 navios e 140000 homens, a que Cartago se opôs com uma frota de guerra composta por 350 navios e equipada com 150000 homens (os números de Políbio estarão algo inflacionados, mas dão uma ideia da magnitude das forças em presença). Os Romanos desejavam desembarcar em África (levavam 500 cavalos a bordo e muitos navios de transporte, rebocados por navios de guerra), mas os Púnicos tentaram gorar este plano, forçando os adversários a travar um combate ao largo da Sicília. 
Tal foi o cenário para a grande batalha naval de Écnomo (perto de Agrigento), provavelmente um dos maiores combates navais da história do Ocidente. Os Romanos dispuseram-se em três linhas, formando um triângulo com uma fila de reserva posicionada mais atrás; Régulo comandava a ala direita e Vulsão a ala esquerda. Quanto aos Cartagineses, com Amílcar liderando ao centro, organizaram uma linha perpendicular à costa e um flanco esquerdo disposto em diagonal com terra; na direita, Hanão chefiava os navios mais rápidos, tratando de ultrapassar o flanco esquerdo romano para facilitar o envolvimento. O plano púnico consistia em fragmentar a compacta formação romana, para que as alas pudessem depois abater-se sobre a retaguarda e os flancos adversários; através de muitos pequenos recontros, tentar-se-ia evitar os ataques frontais dos Romanos, por causa do "corvo", ao mesmo tempo que se privilegiaria a superioridade púnica nas manobras de abalroamento. O plano era bom, mas a vitória sorriu a Roma: depois de derrotarem Amílcar, ao centro, os cônsules conseguiram reunir navios suficientes e conduziram-nos em socorro do resto da armada; os Cartagineses não encontraram antídoto para os "corvos" e, apesar de terem logrado dividir a frota adversária, não foram felizes na hora de abordar e capturar os navios romanos, talvez por levarem menos soldados a bordo.

Depois desta grande vitória, a frota romana regressou à Sicília, para reparar os navios e recuperar as embarcações capturadas. Feito isso, Vulsão e Régulo zarparam para África, tendo desta feita conseguido alcançar sem dificuldade o cabo Bom (a norte de Cartago) e desembarcado nas proximidades da cidade de Áspis (a que os Romanos chamariam Clúpea), que ficava a leste da capital púnica. Áspis foi cercada e tomada pelos Romanos, seguindo-se alguns saques e outras conquistas menores na região (como Kerkouane, ligeiramente a norte), posto o que Vulsão regressou a Itália com o grosso da frota, enquanto Régulo permanecia em África com o exército terrestre (c. 15000 infantes e 500 cavaleiros), apoiado por 40 navios. Ameaçada de perto, Cartago organizou a sua própria defesa, sob o comando de Asdrúbal (filho de Hanão), de Bostar e de Amílcar (o comandante supremo da Sicília, que veio também apoiar). Desconhecemos os efetivos às ordens deste comando púnico tripartido, mas sabemos que dispunham de uma cavalaria numerosa e de muitos elefantes. 
Confiante, Régulo avançou e, em finais de 256 a. C., cercou Adis (a sul de Cartago). Os Púnicos reagiram e empreenderam a construção de um acampamento fortificado numa colina sobranceira à cidade, num terreno acidentado (pouco conveniente para a cavalaria e para os elefantes). Perante a relutância dos comandantes cartagineses para arriscar uma batalha, Régulo optou por forçar o combate, organizando um ataque de surpresa ao acampamento inimigo, de madrugada. A ousadia foi recompensada, e a vitória coube aos Romanos, que avançaram logo para a captura de Tunes, que, por estar situada ligeiramente a sudoeste de Cartago, se tornou uma bela base de operações. Cartago estava agora à beira do colapso, tanto mais que travava simultaneamente uma luta renhida contra os reinos númidas!

Em finais de 256 e inícios de 255 a. C., Régulo tentou negociar a paz, de modo a sair em ombros ainda antes do termo do seu mandato consular (as eleições realizavam-se em março). Contudo, as condições que exigiu aos seus adversários foram de tal forma leoninas que Cartago as rejeitou e optou por reconstruir o seu exército durante o resto do inverno. Foi nessa altura que chegaram à capital africana 50 a 100 mercenários gregos, entre os quais Xantipo, um chefe treinado em Esparta, muito experiente na arte da guerra, que tratou de renovar o exército púnico e conduziu depois as suas forças (12 000 infantes, 4000 cavaleiros e 100 elefantes) em busca de Régulo.

Foi assim que se deu a batalha de Tunes, em 255 a. C., que veio a constituir a única vitória cartaginesa em terra durante a Primeira Guerra Púnica. Os Púnicos acamparam a escassos $2 \mathrm{~km}$ dos Romanos, e, crendo-os debilitados, Régulo optou por atacá-los sem cuidar de proteger a sua cavalaria (posicionada nos flancos e muito menos numerosa do que a adversária). Este erro, assim como a boa prestação dos elefantes, alinhados ao centro, explicam a estrondosa derrota romana: só 2000 soldados conseguiram escapar e o próprio Régulo foi aprisionado e torturado.

A vitória cartaginesa em Tunes operou uma reviravolta na guerra, que se estendeu à Sicília e à Numídia, onde Cartago reforçou as suas posições. A partir daqui, e até ao fim da Primeira Guerra Púnica, Roma não mais tentaria desembarcar um exército em África, limitando-se à realização de algumas incursões costeiras. Para agravar a situação, ainda em 255 a. 
C., depois de uma bem-sucedida operação de resgate dos sobreviventes romanos de Tunes (com uma vitória naval no cabo Hermeu, a norte de Áspis), a esquadra romana sofreu um desastre no seu regresso à Sicília: desejando atemorizar as cidades da costa sudoeste da ilha, favoráveis a Cartago, como forma de induzir a defeção de algumas, a esquadra foi apanhada por uma tempestade nas proximidades de Camarina (no sul da Sicília); de entre 364 navios, só se salvaram 80 !

Roma reagiu e, em apenas três meses de 254 a. C., reconstruiu a sua frota. Assim, 220 navios (provavelmente já não equipados com o "corvo", que, devido ao peso excessivo que causava na proa, pode ter contribuído para o desastre de Camarina) partiram de Itália para Messina, onde se juntaram aos 80 barcos sobreviventes; depois, atacaram e conquistaram Palermo - antiga Panormus, a cidade mais importante do noroeste da Sicília. Nesse ano, eram cônsules Cipião "Asina" e Aulo Atílio Caiatino, e a bem-sucedida operação panormitana (as defesas foram penetradas no ponto mais próximo do mar e a cidade foi tomada de assalto) animou os Romanos. No ano seguinte (253 a. C.), organizou-se uma razia da costa de África, que terminou em desastre devido à ocorrência de uma nova tempestade, que apanhou a esquadra no seu regresso à Sicília (perto do cabo Palinuro, em Itália), o que levou à destruição de 150 navios...

Para compensar este novo dissabor, em 252 a. C., os Romanos conseguiram conquistar Lipara, negando assim aos Cartagineses o controlo das importantes ilhas Líparis; no mesmo ano, Roma apoderou-se também de Termas (a sudeste de Palermo). Em 251 a. C., os Cartagineses reforçaram o seu exército na Sicília e, em finais de 250, Asdrúbal decidiu avançar sobre Palermo, contra Lúcio Cecílio Metelo, o comandante romano da praça. Metelo, que fora cônsul no ano anterior, organizou bem a defesa e, simulando relutância em combater, atraiu os Cartagineses para junto da muralha; a manobra causaria o desastre das tropas de Asdrúbal, com os elefantes massacrados por tiros disparados a partir das muralhas, com a realização de surtidas letais e com o destacamento de velites (infantaria ligeira) no exterior dos muros, fustigando os soldados púnicos. Foi o último grande combate terrestre desta guerra, e o seu resultado encorajou os Romanos, que, ainda em 250 a. C., 
decidiram cercar Lilibeu, uma importante praça na zona ocidental da Sicília, perto das ilhas Égates.

Este assédio foi aparatoso, tendo envolvido dois exércitos consulares e uma esquadra de 200 navios. Os cônsules desse ano eram Gaio Atílio Régulo e Lúcio Mânsio Vulsão Longo, dois repetentes. A operação envolveu diversas obras de cerco e a construção de aríetes, com especialistas fornecidos a Roma por Hierão de Siracusa. Os Cartagineses defenderam-se bem, sob a liderança de Himilcão, fazendo surtidas bastante eficazes contra o acampamento e as máquinas de guerra romanas; nestas circunstâncias, o cerco arrastou-se. A marinha romana conseguiu bloquear o porto, mas Aníbal ludibriou o bloqueio e abasteceu Lilibeu com mantimentos e com 10000 mercenários. Um outro Aníbal, conhecido por "o Ródio”, também enganou diversas vezes a marinha inimiga e garantiu contactos com Cartago e algum aprovisionamento. Por fim, o exército romano conseguiu selar Lilibeu com rochas e entulho e bloqueou uma passagem que conduzia ao porto; na altura, um veloz "quatro" púnico que ali se encontrava encalhado foi apreendido e passou a servir de navio patrulha, tendo acabado por aprisionar o próprio "Ródio". O cerco prosseguia, mas a vantagem romana era evidente, apesar das baixas; para consolidar posições, o senado enviou mais 10000 remadores para a Sicília.

Como forma de pressionar a resistência cartaginesa em Lilibeu, no ano seguinte (249 a. C.) o cônsul Públio Cláudio Pulcro decidiu atacar a base púnica de Drépano (a norte de Lilibeu), e daqui veio a resultar uma nova batalha naval, que terminou com a vitória cartaginesa. Adérbal, o almirante de Cartago, apercebendo-se da aproximação dos Romanos, acelerou e fez-se ao mar, para não ser encurralado no porto; conseguiu o seu objetivo por um triz, circulando a remos, com os barcos em fila indiana, enquanto os adversários entravam no porto pelo lado sul... A manobra, de todo inesperada, lançou a confusão no seio da esquadra romana, que reagiu e acabou por conseguir formar uma linha de batalha, com os esporões apontados ao mar alto; contudo, Adérbal flanqueou a posição romana e obrigou os inimigos a combater de costas para terra. Esta foi a única derrota significativa da marinha romana em toda a guerra; ao todo, devem ter estado envolvidos no combate de Drépano 100 a 130 navios, de cada lado. 
A derrota romana deve ter-se ficado a dever ao facto de os barcos terem sido forçados a combater numa posição muito ingrata, com as popas perto da costa, sem poderem evitar o combate e ganhar velocidade; além disso, os navios romanos já não deviam dispor do "corvo", um grande dissuasor dos ataques frontais. Assim, pela primeira vez, Cartago pôde pôr em campo a sua perícia no abalroamento, com os barcos atingindo os adversários e, depois, recuando sem risco de serem enganchados. Os navios romanos não tiveram espaço para manobrar e para evitar os esporões inimigos, ou para se auxiliarem mutuamente: muitas embarcações foram ao fundo, encalharam ou foram simplesmente abandonadas, e só trinta conseguiram escapar, incluindo o navio almirante de Cláudio Pulcro (que seria mais tarde julgado em Roma, por alta traição).

Ainda em 249 a. C., registou-se um outro desastre romano no mar: o parceiro consular de Pulcro, Lúcio Júnio Pulo, comandava um comboio de 800 cargueiros escoltados por 120 navios de guerra, que transportava cereais para o cerco de Lilibeu; a caminho da Sicília, este comboio desorganizou-se, tendo uma parte dele sido atacada pelos Cartagineses (comandados por Cartalão) enquanto a outra, com o cônsul Pulo, foi apanhada por uma tempestade surgida depois do cabo Paquino, tendo-se despedaçado contra a costa. Depois destes acontecimentos infelizes, o senado suspendeu durante algum tempo a opção pela guerra naval e nomeou Aulo Atílio Caiatino como ditador, tendo este antigo cônsul assumido pessoalmente o comando do exército da Sicília.

$\mathrm{O}$ ano de 248 a. C. conheceu a continuação dos assédios romanos a Lilibeu e a Drépano. Em 247, entrou em cena Amílcar Barca, na opinião de Políbio o comandante mais talentoso de toda a Primeira Guerra Púnica. Amílcar instalou-se perto de Palermo, na colina de Hercte, uma base bastante segura e que dominava um bom ancoradouro. Durante três anos (até 244 a. C.), combateu rijamente os Romanos na Sicília, tendo obtido uma série de vitórias, mas de pequena escala e sem influência decisiva. No ano de 244 a. C., Amílcar Barca tomou a cidade de Érix (na zona ocidental da Sicília, muito perto de Drépano), graças a um ataque de surpresa. Até ao termo da guerra, aguentaria esta posição, com pequenos sucessos obtidos em incursões pontuais: o facto de Cartago estar 
também em guerra com as tribos indígenas do Norte de África deve ter privado Amílcar dos efetivos necessários a manobras mais ambiciosas.

Aos poucos, as operações terrestres na Sicília tornaram-se quase irrelevantes e, perante o arrastar do conflito, em finais de 243 ou já em 242 a. C., Roma decidiu reconstruir a sua frota. Foram fabricados 200 "cincos", copiados (com adaptações) do navio de Aníbal "o Ródio" capturado em Lilibeu. Isto permitiu a um dos cônsules de 242, Gaio Lutácio Cátulo, acompanhado pelo pretor Quinto Valério Faltão, atuar com sucesso na Sicília: apoderaram-se do porto de Drépano e isolaram a vizinha Lilibeu por mar, impedindo também que Amílcar Barca continuasse a ser abastecido por via marítima. Ao mesmo tempo, investiram no treino da esquadra, numa fase em que Cartago tinha a sua marinha meio adormecida e parece ter levado demasiado tempo a reunir equipagens para 250 navios, que foram finalmente enviados para a Sicília a fim de abastecer as guarnições púnicas e de, sob o comando de Hanão, enfrentar o inimigo.

No primeiro trimestre de 241 a. C., as duas frotas rivais estavam posicionadas ao largo das ilhas Égates, na região mais ocidental da Sicília. Os Cartagineses, agrupados na ilha mais a poente (a "Sagrada"), aguardavam vento favorável para poderem rumar a Érix sem serem notados, mas Catulo, avisado, deslocou-se para outra das ilhas. A 10 de março, Hanão dispôs por fim do vento ocidental que tanto desejava e decidiu avançar. Coube então a Catulo tomar uma decisão difícil: intercetar a esquadra púnica (navegando contra a ondulação e expondo-se a mais um desastre natural) ou protelar o ataque e permitir, com isso, que Hanão e Amílcar Barca reunissem as suas forças? Catulo decidiu arriscar, e daí resultou a famosa batalha naval das ilhas Égates, que terminaria com a vitória da esquadra romana, composta por embarcações mais rápidas e mais facilmente manobráveis, logo mais bem preparadas para o abalroamento. Tanto quanto se sabe, os Romanos afundaram 50 navios púnicos (20 dos quais com a tripulação toda a bordo) e capturaram outros 70; do lado romano, registaram-se 30 embarcações afundadas e outras 50 danificadas. Especialmente impressionantes foram os números dos prisioneiros púnicos: Políbio calcula-os em 10 000, enquanto outras fontes os situam entre os 4000 e os 6000; ao que parece, não foram mais porque, a meio 
da batalha, o vento virou para leste e permitiu que muitos navios cartagineses escapassem.

Obtida esta vitória, Cátulo insistiu no cerco a Lilibeu. Nesse momento, porém, desprovida de navios de guerra e sem recursos humanos para prosseguir a luta, Cartago pediu a paz, que seria negociada entre o cônsul romano e um oficial de Amílcar Barca, de nome Gisgão. Estava-se ainda em 241 a. C. e Cátulo queria concluir a guerra o mais depressa possível, antes de o seu mandato acabar, motivo que terá facilitado a conciliação das partes, que depressa acordaram em quatro cláusulas principais: abandono da Sicília pelos Cartagineses; compromisso entre os dois opositores de não fazerem a guerra aos aliados do outro; libertação gratuita dos prisioneiros romanos e resgate dos detidos cartagineses; e pagamento, por Cartago, de uma indemnização de 2200 talentos. Todavia, em Roma, os Comitia Centuriata acharam as cláusulas brandas e agravaram a indemnização para 3200 talentos (dos quais 1000 pagos a pronto), além de obrigarem Cartago a evacuar todas as pequenas ilhas existentes entre a Sicília e África...

Roma não só vencera a guerra como alcançara o seu objetivo mais ambicioso: expulsar os Cartagineses da Sicília! Cartago deixava de poder dominar o Mediterrâneo ocidental, embora se mantivesse forte em África, na Hispânia e na Sardenha. Roma não tentou integrar Cartago na sua rede de "aliados", mas cerca de 227 a. C. seria nomeado um governador para a Sicília, que assim se tornou a primeira "província" romana.

Com o termo da Primeira Guerra Púnica, a situação política em Cartago deteriorou-se, e em 240 eclodiu a "Guerra Mercenária", que se prolongaria por três anos. Os veteranos sicilianos de Amílcar Barca sentiram-se traídos por Cartago (que tentou reduzir o soldo inicialmente acordado) e revoltaram-se. Eram cerca de 20000 mercenários, liderados por um líbio, por um escravo fugido da Campânia e por um gaulês, e conseguiram recolher fortes apoios no seio do campesinato líbio (farto de impostos e do recrutamento militar cartaginês) e entre os príncipes da Numídia. A revolta alastrou e levou mesmo ao bloqueio de Cartago: a cidade viu-se e desejou-se para travar a insurreição, e valeu a força e o talento de Amílcar Barca para sanar o coflito. Finalmente, em 237 a. C., a rebelião foi esmagada com inusitada crueldade. 
Durante esta crise, Roma começou por não se aproveitar da situação e até ajudou Cartago, proibindo os mercadores romanos em África de abastecer os mercenários e autorizando a devolução gratuita dos prisioneiros púnicos ainda retidos. Porém, em 240-239 a. C., os mercenários púnicos da Sardenha também se revoltaram, acabando por ser expulsos da ilha em 238 ou em 237; fugiram para Itália e abordaram o senado, solicitando o seu auxílio. Então, Roma não resistiu e enviou uma expedição militar para ocupar a Sardenha. Perante os protestos de Cartago, os Romanos ameaçaram com uma nova guerra, que os Púnicos, obviamente, não estavam em condições de travar...

Deste modo, poucos anos depois da paz de 241 a. C., Cartago foi obrigada a capitular uma segunda vez: aceitou a conquista romana da Sardenha e da Córsega e comprometeu-se ao pagamento de uma indemnização adicional de 1200 talentos. Como seria de esperar, este oportunismo romano gerou um intenso rancor em Cartago. Enquanto isso, Roma entregou-se, na década de 230, à conquista da Sardenha, que se revelaria bastante árdua, devido à forte resistência sarda.

Com a Sicília, a Sardenha e a Córsega perdidas, Cartago virou-se então para a Hispânia. Amílcar Barca foi enviado para administrar esta província púnica - no início, uma pequena província, que cobria apenas uma pequena área no sul, com o seu coração em Gades, na foz do rio Bétis. Até 229 a. C., Amílcar - que partira, talvez, saturado da incompetência da velha aristocracia púnica e desejoso de exercer um comando militar ilimitado - promoveria uma expansão assinalável da presença cartaginesa na Hispânia. Mas, em 229 a. C., foi morto numa emboscada perpetrada pela tribo celtibérica dos Oretanos, e a liderança cartaginesa passou para as mãos do seu cunhado e vice-comandante, Asdrúbal. Este prosseguiu o programa expansionista (embora com mais diplomacia: chegou mesmo a casar-se com uma princesa hispânica), mas acabou por ser assassinado, em 221 a. C. Neste contexto, o exército cartaginês da Hispânia entregou o comando ao filho mais velho de Amílcar: Aníbal Barca, que contava então 26 anos de idade. Em Cartago, a Assembleia do Povo ratificou esta eleição, que mudaria por completo o curso do conflito entre Romanos e Cartagineses. 
Os Barcas construíram na Hispânia uma espécie de principado semi-independente, assente num exército bem preparado e leal à sua família, que governava em proveito próprio mas sem nunca perder de vista a ideia de uma desforra sobre os Romanos. Nesta Hispânia distante, onde os Celtiberos se haviam instalado a norte, os Iberos ao centro e a sul, e os Lusitanos a oeste, os Barcas fundaram cidades importantes, entre as quais Nova Cartago (a atual Cartagena), na costa sudeste da península.

Roma observava com apreensão o expansionismo púnico na Hispânia e procurava impor-lhe limites. Em 226 a. C., o senado, talvez preocupado com a sua velha aliada Massília (Marselha), impôs a Asdrúbal a promessa de não se expandir para além do rio Ebro, que passa em Saragoça e desagua a sul de Barcelona. Ao mesmo tempo, Roma, enquanto procurava expandir-se para fora da península itálica (cf. as guerras de 228 e 219 a. C., na Ilíria, a pretexto da pirataria), assumia como principal preocupação o controlo do Norte de Itália, onde as tribos gaulesas viviam em tensão permanente com as colónias latinas aí instaladas à força, em especial depois da lei agrária do tribuno da plebe Gaio Flamínio, aprovada em 232 a. C.

Em 225 a. C., uma grande revolta tribal encabeçada pelos Boios e pelos Ínsubres conduziu à invasão da Etrúria por 70000 guerreiros, obrigando Roma a um esforço suplementar, que seria recompensado pela vitória obtida na batalha de Télamon pelos cônsules Lúcio Emílio Papo e Gaio Atílio Régulo. Nos anos seguintes, deram-se mais vitórias consulares no Norte de Itália, e o próprio Flamínio venceu os Ínsubres e os Cenomanos, em 223 a. C. Um ano depois, o senado rejeitou a paz com os Gauleses e Marco Cláudio Marcelo forçou o levantamento do cerco de Clastídio e matou em combate singular o rei gaulês Britomaro, enquanto, pelo seu lado, Gneu Cornélio Cipião tomava de assalto Milão - a capital dos Ínsubres. Estes sucessos levaram a uma rendição tribal generalizada e à instalação de novas colónias romanas no Norte de Itália: Cremona e Placência, nas margens do rio Pó, ambas pensadas para 6000 colonos. O que o êxito militar romano não aplacou foi o ressentimento profundo dos Gauleses, obrigados a ceder a Roma terras de primeira qualidade. Talvez isto nos ajude a compreender melhor os episódios da primeira fase da Segunda Guerra Púnica e o lendário sucesso da campanha itálica de Aníbal Barca... 


\section{A Segunda Guerra Púnica (218-201 a. C.)}

Aníbal Barca entregou-se por completo à ideia de construir na Hispânia um exército capaz de cumprir o sonho mais ambicioso do seu pai: fazer de novo a guerra contra os Romanos. Na Hispânia, os Cartagineses acederam a metal precioso em quantidade suficiente para financiar este plano e para recrutar um elevado número de bons guerreiros tribais.

Por isso, em 220 a. C., quando eclodiu um conflito entre a cidade de Sagunto (perto de Valência), que seis anos antes se tinha tornado aliada de Roma, e uma tribo vizinha que era amiga de Cartago, Aníbal sentiu-se em condições de forçar o confronto: apesar dos protestos de Roma, cercou Sagunto, que acabou por capitular em finais de 219 ou já nos inícios de 218 a. C., ao fim de oito meses de assédio. A população foi reduzida à escravatura e o senado, furioso, exigiu que Cartago castigasse a ousadia do jovem Barca. Nos inícios de 218 a. C., os dois cônsules em final de mandato (Lúcio Emílio Paulo e Marco Lívio Salinator) integraram uma embaixada ao Norte de África, chefiada pelo prestigiado senador Quinto Fábio Máximo. As fontes contam que Fábio levava nas dobras da sua toga a paz e a guerra, e que deixaria cair aquela que os Cartagineses escolhessem; o sufeta púnico, em ambiente de grande exaltação, exortou Fábio a que fosse ele a decidir, e o líder da delegação romana optou pela declaração de guerra, que os Púnicos aceitaram, acalentando a esperança de uma desforra exemplar.

Neste contexto, Aníbal começou a preparar a grande expedição. A ideia consistia em invadir a Itália por terra, a partir da Hispânia, atravessando o rio Ebro (o limite expansionista que havia sido imposto a Asdrúbal), entrando na Gália, cruzando os Alpes e atingindo, por fim, o Norte de Itália. O projeto era temerário, mas não deixava de ser compreensível, tendo em conta que o destroço naval sofrido por Cartago, assim como a perda das ilhas mediterrânicas mais importantes e a ausência de boas bases marítimas tornariam difícil conduzir uma nova guerra por mar. Além disso, Aníbal contaria com o apoio de muitas tribos gaulesas do Norte de Itália, ressentidas com Roma.

No final da primavera de 218 a. C., tendo deixado o seu irmão Asdrúbal à frente da província cartaginesa da Hispânia, Aníbal Barca partiu de Nova 
Cartago com um exército de mais de 100000 homens (c. 90000 peões e 12000 cavaleiros) e 37 elefantes. A maior parte destes homens, de diversas nacionalidades, provinha da península hispânica, incluindo muitos Iberos, Lusitanos e Celtiberos. Tratava-se da maior hoste jamais reunida por Cartago, e a sua deslocação implicava um esforço logístico gigantesco e uma preparação minuciosa, que deve ter demorado perto de dois anos.

Não conhecemos o itinerário exato da hoste cartaginesa, que terá percorrido um pouco mais de $500 \mathrm{~km}$ até alcançar o rio Ebro, marchando em três colunas, para não congestionar as rotas e para facilitar o abastecimento. A partir daqui, e até aos Pirenéus, que cruzaria sagazmente no tempo das colheitas e já sem a sua bagagem mais pesada, Aníbal teve de enfrentar numerosos perigos e múltiplos ataques de tribos variadas. A determinada altura, o general optou por reduzir a sua hoste, mandando perto de 10000 soldados hispânicos regressar a casa, o que, somado às baixas e às deserções, fez com que entrasse na Gália com 'apenas' 50000 peões e perto de 9000 cavaleiros.

A travessia do rio Ródano, que desagua em Marselha, não foi fácil, devido à largura deste curso de água e à oposição de algumas tribos gaulesas que houve que ludibriar para concretizar a passagem (dos homens e dos elefantes!). Superado este obstáculo, Aníbal entrou em negociações com representantes das tribos gaulesas transalpinas, cuja colaboração seria essencial para a invasão do Norte de Itália.

Provavelmente, foi nesta altura que Aníbal teve notícia das movimentações militares dos Romanos. Esperando uma sequência de ataques na região mediterrânica, o senado distribuíra os dois cônsules eleitos em 218 a. C. de uma forma lógica: Tito Semprónio Longo fora enviado para a Sicília, com o objetivo de invadir o Norte de África e pressionar a capital púnica; e Públio Cipião fora mandado avançar para a Hispânia, de forma a atacar diretamente Aníbal, em resposta ao cerco e tomada de Sagunto. Cipião viajou por mar de Pisa até Marselha, onde tencionava embarcar o seu exército para a península ibérica; porém, quando aqui chegou, recebeu a informação de que os Cartagineses já haviam cruzado os Pirenéus e atravessado o rio Ródano, a caminho dos Alpes! A notícia apanhou de surpresa os Romanos, habituados a uma postura bélica mais defensiva 
dos Púnicos, mas Cipião reagiu depressa e alterou os seus planos, tentando ir de imediato em busca do adversário. Tarde demais: prevenido da chegada da esquadra romana a Marselha, Aníbal acelerou a marcha e escapou por três dias... Com a bagagem principal já a bordo dos navios e com escasso aprovisionamento, os Romanos nada mais conseguiram do que travar pequenas escaramuças com alguns destacamentos de batedores ao serviço de Aníbal Barca.

Perante esta situação, Cipião, contactado o senado, entregou o comando da maioria das suas tropas ao irmão Gneu (que as conduziria depois, por via marítima, de Marselha até à Hispânia), regressando ele próprio a Itália, para assumir o comando das tropas do vale do Pó, em luta contra os Gauleses. Ao mesmo tempo, o senado contactou o cônsul Semprónio Longo, dando-lhe ordens para abandonar a Sicília e para se vir juntar às forças de Públio Cipião, de modo a que Aníbal tivesse uma receção adequada...

Os Cartagineses, porém, foram mais rápidos do que os Romanos previam: no início de novembro de 218 a. C., já eles iniciavam a travessia dos Alpes, beneficiando de um forte apoio logístico (cereais, armamento, botas e roupas quentes) proporcionado pelo líder de uma tribo gaulesa, Braneu, que Aníbal ajudara a firmar no trono. Na subida dos Alpes, o general foi obrigado a enfrentar a ameaça dos Alóbroges (repelindo ataques perigosíssimos em zonas de desfiladeiro e outras investidas, com os elefantes a desempenharem um papel de relevo) e a suportar a neve e o frio; as tropas estiveram à beira do colapso, e Aníbal viu-se e desejou-se para manter os níveis anímicos; a descida dos Alpes, já com a Lombardia à vista, foi ainda mais difícil, sobretudo para os animais, devido ao risco das avalanches. Finalmente, duas a três semanas após o início da travessia, isto é, em meados ou finais de novembro de 218 a. C., o exército cartaginês alcançou as planícies a sul das montanhas e entrou no Norte de Itália, pela região da atual cidade de Turim. Nessa altura, já seriam apenas 20000 peões e 6000 cavaleiros, ou seja, uma quarta parte dos que haviam partido de Nova Cartago, cinco meses antes. O destroço fora grande, mas pode bem dizer-se que Aníbal conseguira a sua primeira vitória, logo tratando de engrossar a sua hoste (repleta 
de soldados experientes e leais aos Barca) com um grande número de guerreiros gauleses em luta contra Roma.

Como os cônsules tinham demorado demasiado tempo a concretizar as manobras ordenadas pelo senado, Aníbal pôde enfrentar as forças de Públio Cipião ainda antes de estas serem reforçadas pelas de Semprónio Longo. Foi junto ao rio Ticino, em novembro de 218 a. C., que se deu o primeiro combate, travado sobretudo por forças de cavalaria. Os Cartagineses venceram de forma categórica e Cipião só escapou de ser morto graças ao socorro que lhe foi prestado, em desespero de causa, pelo seu filho Públio Cornélio, a quem a Fortuna reservaria um futuro grandioso.

Os sobreviventes romanos fugiram para Placência, onde as tropas do cônsul Longo se lhes juntaram poucas semanas depois. Foi perto desta cidade, junto ao rio Trébia, que, a 22 de dezembro, se deu uma nova batalha, opondo as forças de Aníbal (que já aumentara os seus efetivos para 28000 peões e 10000 cavaleiros) ao exército conjunto dos dois cônsules romanos, estimado em 36000 a 38000 infantes e 4000 cavaleiros. Neste segundo combate, Aníbal pôde ocupar previamente o terreno e conseguiu esconder cerca de 2000 homens numa vala de drenagem, sob o comando do seu irmão Magão Barca; nas alas, o general cartaginês colocou a sua melhor cavalaria, enquanto 32 elefantes foram dispostos como reforço lateral da infantaria púnica. Quando a batalha começou, a infantaria legionária romana, posicionada ao centro, conseguiu alguma vantagem sobre a sua opositora direta; porém, nas alas, o combate foi desequilibrado, com os Cartagineses (em superioridade numérica) a ganharem vantagem desde muito cedo; liberta dos seus adversários, a cavalaria de Aníbal pôde depois envolver o exército inimigo pelos flancos, enquanto Magão saía da sua emboscada e se lançava sobre a retaguarda romana, assegurando a segunda vitória cartaginesa em Itália.

Aníbal estava imparável, e o senado romano tremia perante a humilhação da sua arrancada para sul, devastando o país e atraindo cada vez mais gauleses, que reforçavam a hoste púnica com efetivos e com provisões. Chegou o inverno de 218-217 a. C. e a guerra acalmou um pouco. Mas, logo a seguir, Aníbal preparou-se para atravessar os Apeninos, o que levou o senado a enviar os novos cônsules para controlar os dois 
possíveis itinerários cartagineses: Gneu Servílio Gémino foi estacionado em Arímino (atual Rimini), enquanto Gaio Flamínio se colocou mais a poente, na Etrúria, junto às montanhas de Arécio. Todavia, Aníbal (que parece ter perdido um olho nesta operação) ludibriou uma vez mais os planos romanos: acelerou a marcha, seguiu por uma estrada imprevista (através dos terrenos pantanosos da Toscana, em torno do rio Arno) e, quando os cônsules deram por isso, já ele havia passado e se encontrava bem mais a sul do que o esperado... Em resposta, Flamínio ensaiou uma perseguição da hoste inimiga, numa manobra que lhe seria fatal: informado pelos seus batedores, Aníbal, ao alcançar as margens do lago Trasimeno e já com os Romanos à vista, aproveitou a noite e o nevoeiro para voltar um pouco para trás e emboscar Flamínio junto à estrada principal. O ataque deu-se a 21 de junho de 217 a. C., e dele resultou a chacina do exército de Gaio Flamínio (entre 25000 e 30000 homens) e a morte do próprio cônsul! A cavalaria do outro magistrado, Gémino, apareceu pouco depois, mas nada pôde fazer e ainda foi, ela própria, massacrada. É certo que os Cartagineses também sofreram baixas relevantes (1500 a 2000 homens), mas o saldo foi extremamente positivo e a operação revelou o génio militar de Aníbal, que colocou o senado à beira de um ataque de nervos...

Foi então que Roma decidiu nomear um ditador por seis meses. O escolhido foi Quinto Fábio Máximo, que já fora cônsul duas vezes e que, do alto dos seus quase 60 anos, tinha grande experiência política e militar. Para auxiliar Fábio Máximo, como "mestre de cavalaria”, o senado escolheu um outro antigo cônsul: Minúcio Rufo. Os dois recrutaram e organizaram rapidamente um novo exército romano, aproveitando o que restara das legiões de Gémino e acrescentando novas unidades. Assim, Fábio e Rufo passaram a dispor de quatro legiões (um pouco menos de 20000 homens, dos quais cerca de 7\% a cavalo) e de quatro "alas" de tropas auxiliares (em número aproximado de soldados). Embora numeroso, tratava-se de um exército pouco experiente e frágil em cavalaria, devido também ao desastre sofrido no lago Trasimeno; por isso, Fábio Máximo optou por uma estratégia prudente, que lhe valeu a alcunha de Cunctator ("hesitante" ou "protelador"): acompanhou os movimentos de Aníbal no centro e sul de Itália, pressionou-o, acossou-o, fustigou a 
coluna cartaginesa com ataques cirúrgicos (nomeadamente a batedores e a destacamentos de angariação de forragens e alimentos), mas evitou sempre travar uma batalha campal.

A certa altura, no final do verão de 217 a. C., na região do ager Falernus, na planície da Campânia, Fábio, um general arguto, vislumbrou uma boa oportunidade para emboscar Aníbal, quando este se preparava para atravessar uma passagem estreita. Porém, o general cartaginês teve um improviso brilhante: durante a noite, enviou 2000 bois transportando umas tochas atadas aos cornos para o desfiladeiro, simulando tratar-se da principal coluna cartaginesa, e baralhou os Romanos, que precipitaram um ataque pela encosta abaixo; na confusão que se gerou, produto também do pânico das cabeças de gado, a passagem ficou temporariamente desimpedida e o grosso do exército cartaginês, devidamente formado em coluna de marcha e atento à oportunidade, atravessou incólume a garganta estreita... Quando, no fim do outono de 217 a. C., chegou ao fim o mandato de Fábio Máximo, já o exército de Aníbal estava estacionado em Gerónio, na Apúlia (no sudeste de Itália), onde organizou os seus aquartelamentos de inverno. O exército romano foi então confiado de novo ao cônsul Servílio Gémino e a Marco Atílio Régulo, que substituíra o cônsul Flamínio, morto no lago Trasimeno.

Como seria de esperar, o senado passou grande parte do inverno de 217-216 a. C. a preparar uma grande campanha militar, capaz de acabar de vez com a ousadia da invasão púnica. Decidiu-se que os novos cônsules (Lúcio Emílio Paulo e Gaio Terêncio Varrão) deveriam avançar juntos desde o início, comandando alternadamente um imenso exército. Ambos os magistrados tinham experiência militar e política (Paulo já fora cônsul e fizera a guerra na Ilíria, e Varrão fora questor, edil e pretor) e pareciam capazes de desempenhar bem o seu papel. Ao seu dispor, teriam o maior exército jamais reunido por Roma: oito legiões ligeiramente aumentadas (cerca de 5000 infantes por cada legião, em vez dos habituais 4200, mais os 300 cavaleiros do costume) e oito "alas" de tropas auxiliares (com as mesmas forças de infantaria, mas um pouco mais de cavalaria: cerca de 450 homens montados em cada "ala"); ao todo, perto de 80000 peões e 6000 cavaleiros! Uma parte desses homens provinha das forças reunidas 
e treinadas por Fábio e por Rufo, mas pelo menos quatro das legiões terão sido recrutadas apenas em finais de 217 ou em inícios de 216 a. C., pelo que teriam escassa experiência. Este enorme exército recebeu ordens expressas do senado para enfrentar Aníbal e derrotá-lo em batalha campal; por isso, seguiu diretamente para a Apúlia, em busca do inimigo, que entretanto se deslocara pela costa do Adriático e alcançara a povoação de Canas, onde se apropriara de um imenso depósito de provisões.

A 28 de julho, já depois da junção das forças militares dos novos cônsules às de Gémino (que permaneceu integrado no exército, como procônsul) e de Régulo (que pediu para regressar a Roma), Emílio Paulo e Varrão alcançaram as imediações de Canas. Tratava-se de um lugar protegido a sul por uma linha montanhosa, mas bastante aberto e plano a norte, com muita área cultivada e sem árvores; foi aí que os dois magistrados traçaram o seu plano. Segundo explica Políbio, Paulo teria preferido combater numa região mais montanhosa, para contrariar a superioridade da cavalaria púnica, mas Varrão, atento ao problema do abastecimento e da deslocação de uma hoste tão numerosa, optou por uma batalha quase imediata. Assim, a 29 de julho, dia em que era ele que comandava, Varrão avançou na direção do acampamento púnico, provocando alguma confusão e originando as primeiras escaramuças. No dia seguinte, Paulo mandou o exército romano aproximar-se um pouco mais e, a 30 de julho, Varrão ordenou a instalação de dois acampamentos: o maior na margem norte do rio Ofanto, o outro na margem sul, a cerca de $1,5 \mathrm{~km}$ de distância.

Aníbal observou atentamente as movimentações romanas e respondeu transferindo o acampamento púnico para junto do principal arraial dos Romanos. A mensagem era clara: também o general cartaginês queria travar batalha! A 1 de agosto, Aníbal chegou mesmo a dispor o seu exército em linha de combate, mas Paulo declinou o convite; os Cartagineses retiraram, não sem antes a cavalaria númida fazer um raide relâmpago contra o pequeno acampamento romano instalado do outro lado do rio, lançando o pânico e desmoralizando as tropas aí acantonadas.

Finalmente, chegou o dia do combate de Canas (2 de agosto), uma das maiores batalhas do mundo antigo e a maior derrota da história de Roma. Com Varrão no comando, o exército romano formou as suas linhas para 
lutar; cerca de 10000 homens (talvez uma legião e uma "ala") ficaram de guarda ao acampamento principal, enquanto outros 3000 (porventura não combatentes, semiarmados) guardavam o pequeno acampamento da margem sul do Ofanto. O resto das tropas foi disposto entre o curso de água (que protegia o flanco direito romano) e o sopé da montanha de Canas (que defendia o flanco esquerdo). O espaço era acanhado (a frente romana, virada para oeste teria só 2 ou $3 \mathrm{~km}$ ), mas a solução encontrada por Varrão tinha a vantagem de dificultar o envolvimento pelos flancos. A distribuição das tropas obedeceu ao esquema tradicional: infantaria pesada ao centro (sete legiões e sete alas, c. 70000 homens, sob o comando de Gémino); cavalaria romana à direita (2400 homens, liderados por Paulo) e cavalaria aliada à esquerda (3600 homens, chefiados por Varrão).

O plano de batalha romano consistia em apostar tudo no centro e atribuir às alas um papel de resistência: ou seja, a infantaria legionária decidiria o combate na zona nuclear do campo de batalha, enquanto as alas poderiam soçobrar, sim, mas o mais tarde possível, para manietar a poderosa cavalaria inimiga e proibi-la de atuar noutras zonas do terreno até a infantaria legionária completar o seu trabalho. O ponto mais fraco do dispositivo tinha que ver com a profundidade anormal das linhas romanas (entre 140 e 160 metros), em resultado da estreiteza do campo de batalha, que obrigava a encurtar os intervalos entre os manípulos (os corpos de 120 homens em que se decompunha cada uma das três linhas de uma legião: os hastati, os principes e os triarii); esta disposição facilitaria o amalgamamento das tropas durante o combate, dificultaria o comando das unidades e roubaria flexibilidade tática. Porém, mesmo essa profundidade trazia vantagens: estando, na sua maioria, distantes da linha da frente, os homens sentir-se-iam mais seguros, e também avançariam de forma mais organizada, sem se deixarem afetar pelas irregularidades do terreno.

A esta tática respondeu Aníbal com um dispositivo genial, que ainda hoje é estudado nas academias militares. Na ala esquerda, colocou a sua cavalaria pesada, hispânica e gaulesa, sob o comando de Asdrúbal: 6000 homens, a quem caberia enfrentar, em condições de grande superioridade, os 2400 cavaleiros de Paulo; na ala direita, chefiada por Maárbal 
(ou por Hanão), posicionou a cavalaria ligeira: 3 a 4 mil númidas, que se oporiam, de forma equilibrada, aos 3600 cavaleiros itálicos ao serviço de Varrão; ao meio, Aníbal dispôs 32000 peões: 24000 hispânicos e gauleses ficaram sob o seu comando direto e o de Magão, e dispuseram-se no veio central do terreno, em forma de meia-lua, com o centro avançado e formando uma cunha na direção da infantaria legionária romana, como que convidando-a a atacar; os restantes 8000 peões (a forte infantaria líbia) foram dispostos de forma sublime, em dois corpos de 4000 homens colocados nas zonas laterais do centro, mas em posição recuada e, provavelmente, sem possibilidade de serem avistados pelos Romanos na fase inicial do combate!

Quando a batalha começou, depois das habituais escaramuças entre os corpos de infantaria ligeira (velites romanos contra dardeiros líbios, escudeiros hispânicos e fundibulários das ilhas Baleares ao serviço de Aníbal), Asdrúbal, no flanco esquerdo, atacou de imediato a cavalaria romana de Paulo e depressa a varreu do campo de batalha; esta manobra fez ruir, logo no início, uma parte do plano de batalha romano e obrigou Paulo, ele próprio ferido, a escapar com os homens que pôde para a zona central do terreno, onde se juntaram às forças de Gémino. Liberta de oposição direta, a cavalaria de Asdrúbal foi juntar-se ao corpo chefiado por Maárbal, que travava já, no outro flanco, uma luta renhida com os cavaleiros aliados de Roma, comandados por Varrão. A chegada deste reforço desequilibrou a contenda nessa ala e forçou o cônsul romano a fugir. Nesse momento, Asdrúbal ordenou aos númidas - cavaleiros muito ágeis e velozes - que perseguissem os adversários e os impedissem de reagrupar e de regressar ao campo de batalha; enquanto isso, continuou a sua manobra e foi atacar pela retaguarda o corpo central do dispositivo romano!

Entretanto, ao centro, os legionários de Gémino, atraídos pela cunha adversária e confiantes na sua superioridade no combate corpo a corpo, atiraram-se contra a infantaria de Aníbal e de Magão; ganharam vantagem e obrigaram-na a recuar. Com esta movimentação, a cunha avançada inverteu-se e ganhou, aos poucos, a forma de um U, resultado da pressão dos poderosos legionários romanos e, quiçá, de uma manobra intencional dos Púnicos, visando aplicar o famoso golpe de "tenaz". Quando a 
infantaria pesada romana parecia já cantar vitória, abateu-se sobre ela um verdadeiro pesadelo: os dois corpos de infantaria líbia, escondidos nas zonas laterais do centro, atacaram os Romanos, um de cada lado, ao mesmo tempo que Asdrúbal surgia na retaguarda e fechava o cerco! Envolvidos por todos os lados, sem espaço para manobrar, com os manípulos já misturados uns com os outros e o famoso vento vulturno soprando fortes rajadas de sudeste, que parece terem levantado muita poeira e incomodado bastante os soldados romanos, os legionários lutaram o melhor que puderam, venderam cara a derrota, mas não escaparam à chacina: neste campo de batalha, onde naquela tarde de calor intenso se defrontaram perto de 130000 homens e cavalos em menos de sete ou oito quilómetros quadrados (!), pereceram 50000 soldados romanos (mais de metade do maior exército jamais reunido por Roma), incluindo o cônsul Lúcio Emílio Paulo, o procônsul Servílio Gémino, o antigo mestre das milícias de Fábio Máximo, Minúcio Rufo, dois questores dos cônsules, 29 dos 48 tribunos militares e ainda 80 personalidades de alto gabarito (entre as quais numerosos senadores). Do lado cartaginês, Políbio refere 5700 mortos (c. 11,5\% dos efetivos), enquanto Lívio fala em 8000 baixas (16\%). Dos que sobreviveram, muitos escaparam para Canosa, localidade onde, por iniciativa de Varrão e de quatro tribunos (entre os quais o jovem Públio Cornélio Cipião e o filho de Fábio Máximo), se concentrou o reagrupamento romano. Ao fim de alguns dias foi, por isso, possível formar duas novas legiões, cada qual com 5000 homens, o que evitou males maiores.

Claro que a notícia do desastre de Canas caiu como uma bomba em Roma. Ao sentimento de humilhação e ao luto público pelos falecidos (algo que o senado depressa limitou a 30 dias), somava-se a angústia sobre o que Aníbal iria fazer a seguir: pretenderia atacar Roma? E, se o fizesse, estaria a capital em condições de lhe resistir?

Mas Aníbal, apesar de pressionado por alguns dos seus oficiais, optou por se manter no Sul de Itália. Roma ficava a mais de $400 \mathrm{~km}$, os homens estavam exaustos, não dispunha de máquinas de cerco, e a sua intenção não era conquistar a capital: Aníbal pretendia 'apenas' alargar o seu número de aliados em Itália, de modo a isolar Roma e a obrigá-la 
a assinar um tratado claramente favorável a Cartago, apagando a nódoa do acordo de 241 a. C. Portanto, depois de enterrar os seus mortos e de cuidar dos seus feridos, Aníbal mandou uma embaixada a Roma, com 10 dos 8000 cidadãos romanos capturados, para negociar os resgates e, se possível, a paz. Mas enganou-se: Roma, consultado o oráculo de Apolo em Delfos, castigadas duas virgens vestais e feitos alguns (raros) sacrifícios humanos, recusou receber o emissário cartaginês e tão-pouco se interessou pelo resgate dos prisioneiros... A decisão desapontou Aníbal, que no entanto beneficiou da submissão de uma boa parte do Sul de Itália em finais de 216 a. C., facto que lhe permitiu começar a praticar um outro tipo de guerra, com diversas bases operacionais, embora também com mais aliados para proteger.

Entretanto, em Roma, multiplicavam-se as medidas de reação à crise. Varrão foi mandado regressar e Marco Júnio Pera foi nomeado ditador, cabendo-lhe (e a Tibério Semprónio Graco, seu "mestre de cavalaria") iniciar o processo de reconstrução do exército. Confirmando os enormes recursos humanos da República, rapidamente foram recrutadas duas novas legiões, incorporando jovens de 17 anos e escravos libertados e recorrendo a armamento invulgar, como troféus da guerra contra os Gauleses ou peças retiradas dos templos. No entanto, no imediato, não foi possível mobilizar mais de 1000 cavaleiros, dada a sangria sofrida pela ordem equestre em Canas.

Nas eleições consulares de 215 a. C., o voto recaiu em Lúcio Postúmio Albino e em Tibério Graco. Todavia, o primeiro depressa se deixou apanhar numa emboscada na Gália Cisalpina e acabou morto, juntamente com uma parte importante do seu exército. Por isso, foi substituído por Marco Cláudio Marcelo, o experiente pretor que já havia sido cônsul e que tinha combatido na Sicília e na Gália Cisalpina. Em 214 a. C., Fábio Máximo e Marcelo foram eleitos novamente cônsules e, nos anos seguintes (em que foram sendo, intermitentemente, reeleitos), geriram o melhor possível, com êxitos e com derrotas secundárias, a guerra contra Aníbal, centrada na Apúlia e na Sicília.

Aníbal permaneceu em Itália até 203 a. C., tendo obtido sucessos importantes e alguns reveses amargos. Por um lado, conseguiu que 
uma cidade como Cápua passasse para o seu partido (ao contrário de Nápoles e da maioria das cidades aliadas de Roma) e, em 215 a. C., tomou Casilino (na costa oeste) após um cerco difícil, tendo entregado depois a cidade aos Campanos, com uma guarnição reforçada; em 212 a. C., tomou Tarento, na sequência de uma traição interna, e venceu os Romanos em Herdónia, na Apúlia central, contra o pretor Gneu Fúlvio Flaco e usando um estratagema do tipo utilizado no lago Trasimeno; em 210 a. C., repetiu o triunfo em Herdónia, à custa do pretor Gneu Fúlvio Centumalo e com grandes baixas romanas; e, em 208 a. C., emboscou mortalmente os cônsules Marco Cláudio Marcelo e Tito Quíncio Crispino.

Por outro lado, Aníbal viu Hanão sofrer dois desastres, o primeiro em 214 a. C. (no rio Calor, no centro de Itália, diante do cônsul Graco) e o outro em 212 a. C. (em Benevento, a leste de Cápua); além disso, em 214 a. C., não pôde travar a reconquista de Casilino por Fábio Máximo, apoiado por Marcelo, seguindo-se-lhe a captura de Arpos; fracassou também na região de Nola e, sobretudo, não conseguiu evitar a capitulação de Cápua em 212 a. C., às mãos dos cônsules Ápio Cláudio Pulcro e Quinto Fúlvio Flaco, mau grado ter marchado sobre Roma em 211, para obrigar as legiões a dispersar. Dois anos mais tarde, viu Tarento ser reconquistada pelos Romanos, na última campanha militar de Fábio Máximo.

De uma forma geral, podemos dizer que Aníbal Barca teve razões para lamentar o fraco empenhamento dos seus aliados na guerra contra os Romanos: cada cidade opositora de Roma atuava por si própria, sem coordenação com as restantes, contando com o 'guarda-chuva militar' proporcionado pelo exército cartaginês, o que fez com que tudo dependesse demasiado da intervenção do núcleo duro de Aníbal, que não podia acorrer a todos os perigos. Para ser inteiramente bem-sucedido, o general cartaginês teria precisado de receber reforços significativos, e Magão Barca bem que os foi solicitar a Cartago, em finais de 216 a. C. Porém, devido à falta de portos ou de bases navais sob controlo púnico, e à presença dominadora dos Romanos na Sicília, isso só sucedeu por uma vez, em 215 ou 214 a. C., quando Bomílcar e uma esquadra púnica conseguiram desembarcar tropas, elefantes e provisões em Lócrida, na Calábria. Assim, Aníbal foi ficando cada vez mais encurralado no Sul 
de Itália, vendo os Romanos aumentar o seu poderio militar (as legiões atingiram o número recorde de 23 em 212-211 a. C., o que permitiu a existência de quatro a sete exércitos do tipo consular operando em Itália) e assistindo impotente à defeção de muitos antigos aliados.

Em nosso entender, as dificuldades de Aníbal ficaram também a dever-se a alguns fatores 'externos', muitas vezes ignorados pelos historiadores. Os Cartagineses contariam com uma segunda invasão de Itália a partir da Hispânia, protagonizada por Asdrúbal Barca, que estaria prevista para 216 a. C., mas teve de ser adiada. Com efeito, em finais de 217, após recuperar do ferimento sofrido no rio Ticino, Públio Cipião foi juntar-se ao irmão Gneu, que na Hispânia tinha já obtido alguns sucessos importantes (na região nordeste e na batalha de Cissa, perto de Tarragona, tendo capturado Hanão e a bagagem pesada que Aníbal deixara para trás antes da passagem dos Pirenéus). Assim, as posições romanas na península ibérica tinham avançado bastante, a norte do Ebro, o que manietou Asdrúbal. Na primavera de 217 a. C., este reagira com um ataque anfíbio que partira de Nova Cartago e que chegara à linha do Ebro, mas o almirante cartaginês, Amílcar, fora derrotado por Gneu numa batalha naval na foz daquele rio e, na sequência desta derrota, os Romanos tinham ampliado os seus aliados ibéricos, enquanto os Celtiberos devastavam o território cartaginês.

Em finais de 217 a. C., Gneu e Públio Cipião (que levava ordens do senado para atacar e que se fazia acompanhar por 20 a 30 navios de guerra e por cerca de 8000 homens, com elevado número de provisões) cruzaram o Ebro e reconquistaram Sagunto. Em 216 a. C., Cartago reforçou a posição de Asdrúbal com o envio de tropas, para que este enfrentasse os Romanos na Hispânia e, depois, se juntasse ao irmão em Itália. Porém, na primavera de 215, Gneu e Públio Cipião derrotaram Asdrúbal perto da cidade de Ibera (a sul do rio Ebro), travando uma segunda invasão cartaginesa da Itália.

A guerra hispânica entre Cartagineses e Romanos atingiu então um ponto alto, com Cartago a reforçar a sua posição através de Magão Barca (com forças inicialmente destinadas a Itália) e com Roma a instigar as rebeliões antipúnicas e a avançar inexoravelmente para sul. Nesta altura, os Cartagineses dispunham de três exércitos na Hispânia (o de Asdrúbal 
Barca, o de Magão e o de Asdrúbal Gisgão), mas a coordenação entre eles parece ter deixado a desejar. Ainda assim, aquando de uma grande ofensiva romana ocorrida em 212 (ou já em 211) a. C., Asdrúbal Barca conseguiu aliciar os Celtiberos para a sua causa, enquanto o seu irmão Magão, juntando as suas forças às de Asdrúbal Gisgão e contando também com o apoio do jovem príncipe númida Masinissa (e da sua excelente cavalaria), derrotaram e mataram Públio Cipião em batalha. Depois, os três generais cartagineses juntaram-se e perseguiram Gneu Cipião, que acabou por tombar também, depois de uma resistência heroica. Assim, num só mês, os exércitos romanos da Hispânia tinham sido destruídos, tendo cabido a Lúcio Márcio (um tribuno ou centurião primus pilus) juntar os destroços e acantonar-se algures a norte do rio Ebro, até receber algum reforço de Roma...

O senado, ciente da necessidade de travar Asdrúbal e Magão Barca na Hispânia, reagiu depressa e enviou Gaio Cláudio Nero como novo comandante, que logo na primavera de 210 a. C. obteve uma pequena vitória sobre Asdrúbal Barca. No entanto, a reviravolta ocorreu sobretudo a partir de finais de 210 a. C., quando o comando foi entregue a Públio Cornélio Cipião (o filho mais velho do cônsul de Ticino e Ibera), que tinha então 26 anos, mas já dispunha de muita experiência militar (como vimos, combatera em Ticino e em Canas); terá partido na qualidade de procônsul, sendo acompanhado por um forte exército de 28000 infantes e 3000 cavaleiros. Durante o inverno de 210-209 a. C., começou a preparar meticulosamente o seu grande projeto: nada mais nada menos do que atacar Nova Cartago! Na primavera de 209, avançou por terra, enquanto o seu legado Gaio Lélio viajava por mar; o ataque à capital púnica na Hispânia foi bem-sucedido e esta rendeu-se após uma grande matança. Cipião continuou a treinar as suas tropas e, na primavera de 208 a. C., bateu Asdrúbal Barca na batalha de Bécula (na margem direita do Guadalquivir): apesar da superioridade posicional púnica, forçou o adversário a combater, envolvendo depois o seu exército pelos dois flancos.

Asdrúbal escapou com vida desta batalha, e foi então que decidiu sair da Hispânia em direção a Itália com o seu exército, servindo-se provavelmente da mesma rota utilizada pelo irmão Aníbal. Sucede, todavia, 
que os de Marselha preveniram os Romanos de que Asdrúbal pretendia passar os Alpes e entrar em Itália na primavera de 207! Após algum pânico, estes organizaram-se e o cônsul Marco Lívio Salinator, apoiado pelo pretor Lúcio Pórcio Lícino (com duas legiões colocadas perto de Arímino) e por Gaio Terêncio Varrão (o comandante romano de Canas, que liderava duas legiões na Etrúria) postaram-se à espera de Asdrúbal Barca no Norte de Itália...

Asdrúbal chegou e cercou Placência, sem êxito; a partir daqui, enviou mensagens ao irmão, a quem esperava juntar-se na Úmbria (na Itália central). Todavia, estas missivas foram intercetadas pelos Romanos, que juntaram forças na zona de Senegália, no nordeste de Itália (perto da região do Piceno). O cônsul Gaio Cláudio Nero subiu então, com grande audácia e magnífica organização logística, desde a Apúlia até ao Piceno, sem que Asdrúbal Barca (acampado bem perto) desse pela manobra, e começou a preparar uma batalha campal, mas Asdrúbal, nessa altura, desconfiou e retirou-se para o rio Metauro (entre Arímino e Senegália). Os Romanos perseguiram-no e apanharam-no a montar o seu acampamento, tendo-se então travado a batalha do rio Metauro (207 a. C.). O combate terminou com a vitória romana (graças também a uma manobra de Nero, que se deslocou por trás da linha de batalha e envolveu o flanco direito inimigo) e com a morte de Asdrúbal Barca. Nesta batalha, os Cartagineses terão sofrido perto de 10000 baixas (os Romanos apenas 2000) e tudo isto deitou por terra os planos de Aníbal, que confiava num bom reforço vindo da Hispânia.

Para mitigar as dificuldades cartaginesas, dois anos mais tarde (em 205 a. C.) Magão Barca desembarcou perto de Génova, com 2000 cavaleiros e 12000 infantes (alguns deles recrutados durante o inverno, nas Baleares), tendo depois recebido um reforço de 7 elefantes, 800 cavaleiros e 6000 peões, assim como fundos para recrutar tropas entre as tribos lígures do noroeste de Itália. Aníbal decerto que ansiaria por este reforço, mas também ele não chegou ao seu destino: em 203 a. C., o pretor Públio Quintílio Varo e o procônsul Marco Cornélio Cetego, à frente de quatro legiões, forçaram Magão a combater no território dos Ínsubres; desse combate, resultou a derrota e a morte do mais novo dos irmãos Barca. 
Um outro cenário exterior à península itálica que deve ser considerado é a Sicília. Recuemos um pouco na cronologia: quando começou a Segunda Guerra Púnica, Roma dominava a ilha a oeste e a norte, e Hierão de Siracusa (o velho aliado dos Romanos) a leste e a sul. Em finais de 216 a. C., a guarnição romana era formada pelos sobreviventes da batalha de Canas; no ano seguinte, Cartago quase conseguiu reconquistar a Sicília, valendo a intervenção do cônsul Tito Mânlio Torquato; nos inícios desse ano de 215 a. C. (ou ainda no ano anterior), faleceu também Hierão de Siracusa, tendo-lhe sucedido o neto, Jerónimo, ainda muito novo. Este facto abriu uma crise na ilha, e Jerónimo chegou a negociar com Aníbal, mas parece ter-lhe feito exigências incomportáveis para se opor a Roma; não por acaso, Jerónimo foi assassinado ao fim de escassos 13 meses, e a sua família também.

Neste contexto, deu-se a ascensão na Sicília, em 214 a. C., dos irmãos Hipócrates e Epicides, dois descendentes de um exilado siracusano que se fixara em Cartago; ambos se mostraram favoráveis a Cartago e depressa tomaram a praça de Leontinos (uma das cidades controladas por Siracusa), atacando as bases romanas. Roma reagiu através do cônsul Marco Cláudio Marcelo, que no mesmo ano recuperou Leontinos. Então, os dois irmãos apoderaram-se de Siracusa, enganando os soldados locais, e isso desencadeou uma guerra cruel entre Siracusa e Roma.

Na primavera de 213 a. C., Marcelo (designado procônsul) e Ápio Cláudio Pulcro (propretor) atacaram Siracusa, com engenhos (pontes "sambucas") instalados nos navios ao largo, para atacar as muralhas. Porém, em Siracusa vivia um geómetra genial, o famoso Arquimedes, que inventou uma série de dispositivos engenhosos que frustraram os planos romanos. Marcelo tratou então de bloquear a cidade e devastou os seus arredores. A este ataque respondeu Cartago com o envio de um grande exército (25 000 infantes, 3000 cavaleiros e 12 elefantes), chefiado por Himilcão: desembarcaram em Heracleia Minoa (na costa sul) e ocuparam Agrigento; Marcelo já não chegou a tempo de evitar esta manobra, apenas tendo conseguido derrotar Hipócrates no caminho.

Mais tarde, Hipócrates e Bomílcar (à frente da esquadra púnica) conseguiram romper o bloqueio romano a Siracusa, e Roma enviou reforços para Marcelo, mas ninguém ousava travar a batalha decisiva. Enquanto 
Cartago aliciava deserções a Roma (como no caso de Hena, no centro da ilha), os Romanos perdiam o seu grande depósito de provisões de Murgância (no centro-leste), mas insistiam no cerco a Siracusa.

Em inícios de 212 a. C., perante o arrastamento da situação, Marcelo optou por um assalto-surpresa a Siracusa, que foi bem-sucedido; apesar disso, o bloqueio teve de prosseguir na zona da cidadela e do porto. Himilcão e Hipócrates, que tinham juntado as suas forças, ainda acorreram com um exército de socorro, mas chegaram tarde demais; além disso, uma epidemia devastou o acampamento púnico no outono de 212 a. C., matando os dois líderes! A situação melhorava para os Romanos, mas, ainda assim, a esquadra púnica, sob Bomílcar, continuava a conseguir abastecer Siracusa.

Neste contexto, e depois de os Cartagineses terem recusado uma batalha naval iminente no cabo Paquino, Epicides deu Siracusa por perdida e fugiu para Agrigento. Em finais de 212 a. C., Marcelo conseguiu, pois, tomar Siracusa, tendo Arquimedes sido morto na mesma ocasião. Na sequência deste sucesso, Roma pôde ampliar a sua rede de alianças na Sicília, ficando a resistência cartaginesa polarizada em torno de Agrigento, sob a liderança de Hanão e de Epicides. Más notícias para Aníbal, que enviou para a ilha um bom reforço: o general Mutines.

Em 211 a. C., Marcelo conseguiu derrotar Hanão e Epicides numa batalha junto a Agrigento, regressando depois a Roma com um grande espólio. Mas a guerra prosseguia na Sicília, agora sob a liderança de Mutines, reforçado por tropas enviadas por Cartago. Nesta altura, a forças romanas (basicamente as duas legiões sobreviventes de Canas) sentiram-se algo abandonadas, pelo que, em 210 a. C., o cônsul Marco Valério Levino assumiu o comando na ilha, tendo obtido uma vitória decisiva em Agrigento (ao que parece, com a cumplicidade de Mutines, que Hanão desprezara e demitira). Na sequência disto, Hanão e Epicides fugiram, o que facilitou o reforço da posição romana na Sicília: deram-se então 40 capitulações de cidades, 20 traições e 6 assaltos, tudo em favor da cidade do Lácio! Roma puniu os inimigos e recompensou os seus aliados, incluindo Mutines e Moérico - que tinha entregado a cidadela de Siracusa.

A vitória obtida na Sicília foi extremamente importante para o triunfo de Roma na Segunda Guerra Púnica: se Cartago aqui tivesse vencido, a 
história do conflito teria sido outra. Aliás, os Cartagineses, cientes da importância da Sicília (como fornecedora de cereais e como base naval), bem que investiram nesta guerra, mas a escassa agressividade dos seus comandantes, a peste que grassou no acampamento púnico em Siracusa e a deserção de Mutines goraram completamente os planos de Aníbal. Por outro lado, a maioria das cidades italianas não quis trair Roma, e, com a aristocracia siciliana muito dividida, as infidelidades beneficiaram sobretudo os Romanos.

Uma última observação 'externa' que temos de fazer conduz-nos à Macedónia. É sabido que, possivelmente em 215 a. C., Aníbal entabulou negociações secretas com o rei Filipe V, no sentido da assinatura de um tratado púnico-macedónico contra Roma. Com este acordo, Aníbal pretenderia provocar uma pressão adicional sobre a República romana, enquanto Filipe, que dois anos antes fizera a paz com a Etólia (na Grécia central) e que estava preocupado com o expansionismo romano, ficaria com melhores condições para expulsar os Romanos da Ilíria.

Roma estava alerta relativamente a uma possível invasão macedónica da Itália e, no outono de 215 a. C., enviou o pretor Marco Valério Levino para Brindisi (no extremo sudeste da península itálica), para proteger a costa do mar Adriático e fazer a guerra à Macedónia. Levino respondeu eficazmente ao ataque naval macedónico a Apolónia e Órico (a norte do Epiro), tendo defendido os aliados ilírios de Roma. Em 211 a. C., Roma assinou com a Liga Etólia um tratado contra Filipe V; a aliança (que permitiria à Etólia alargar o seu território e a Roma obter algum saque para financiar as suas operações) demorou a funcionar, mas acabou por se alargar a Élis, a Esparta e a Pérgamo; em resposta, a Liga Aqueia (no Peloponeso) aderiu à causa de Filipe V. Esta repartição de forças e de alianças (sempre precárias na região) levou os Romanos, os Etólios e os seus aliados a atacar Filipe $\mathrm{V}$ em várias frentes, mas o jovem rei macedónio respondeu com talento e energia e, em 207 a. C., atacou a Etólia, enquanto a Liga Aqueia esmagava Esparta na batalha de Mantineia. Esta situação levou a Etólia a ceder e a assinar uma paz com a Macedónia, em 206 a. C.

No ano seguinte (205 a. C.), os Romanos reforçaram a sua presença na região, através do procônsul Públio Semprónio Tuditano, com um 
exército de 11000 homens e 35 quinquerremes. Os combates foram algo inconclusivos e acabaram por levar à assinatura da Paz de Fenice, mediada pelos Epirotas. O acordo consagrou uma situação de equilíbrio, com base em cedências mútuas, e Roma reconheceu a Macedónia como potência independente. Para os padrões romanos, foi uma paz que soube a pouco, mas teve pelo menos uma grande vantagem: privou Aníbal Barca de um forte aliado e, nesse sentido, contribuiu para a vitória romana na Segunda Guerra Púnica.

Aníbal Barca via, pois, cada vez mais portas a fecharem-se à sua volta. Tanto mais que, na Hispânia, Públio Cornélio Cipião ia acumulando êxitos e ameaçava tornar-se um perigo para Cartago. Depois de bater Asdrúbal Barca em Bécula (em 208 a. C.), Cipião venceu igualmente Asdrúbal Gisgão na batalha de Ilipa (em 206 a. C.), usando uma tática genial, em que trocou de dispositivo à última hora, retendo o centro e organizando uma manobra envolvente com as duas alas. Esta vitória conduziu, praticamente, à dissolução do exército púnico na Hispânia e ao domínio esmagador dos Romanos, que organizaram uma série de expedições punitivas contra os chefes tribais rebeldes. Tendo sobrevivido a uma doença grave (durante a qual ocorreu a revolta de Indíbilis contra o cônsul Cecílio Metelo, assim como a rebelião da guarnição romana de Sucro, por soldos em atraso), Cipião conseguiria ainda a rendição da cidade de Gades, o que pôs um ponto final em vários séculos de presença cartaginesa na Hispânia.

Em 205 a. C., Cipião regressou a Itália e foi eleito cônsul. Provavelmente, logo nessa altura terá começado a conceber o plano de passar ao Norte de África e atacar Cartago! Alguns senadores (entre os quais Fábio Máximo) opuseram-se ao projeto, mas Cipião forçou um compromisso favorável e foi autorizado a instalar-se na Sicília, com permissão para passar a África se tal fosse do interesse de Roma...

Na Sicília, Cipião contava com cerca de 25000 a 30000 homens (incluindo as duas legiões de Canas e duas "alas” de tropas auxiliares); apesar de não dispor de mais do que $10 \%$ de cavaleiros, era um bom exército, e o cônsul tratou de o treinar, ao mesmo tempo que preparava o seu ataque a Cartago. Enquanto isso, Gaio Lélio, novamente o legado principal de Cipião, realizava pilhagens navais na costa africana. 
Na segunda metade de 205 a. C., rebentou um escândalo entre os soldados romanos de Lócrida, devido aos abusos do legado Quinto Plemínio, o que quase comprometeu a posição de Cipião. Mas este já havia conseguido a sua nomeação como procônsul e resistiu, beneficiando também do relatório favorável de uma comissão do senado que foi inspecionar a marinha e o exército sicilianos.

Assim, na primavera de 204 a. C., com uma logística bem organizada, o exército de Cipião zarpou da Sicília e, ao fim de dois dias, alcançou sem embaraço o Norte de África. Desembarcaram perto de Útica (a norte de Cartago), derrotaram 500 cavaleiros cartagineses que os vieram fustigar e obtiveram uma adesão importante: a do príncipe númida dos Massilos, chamado Masinissa, que carecia urgentemente do apoio romano porque tinha sido derrotado pelo seu rival Sífax (o rei númida dos Massessilos).

Depois de emboscar uma força cartaginesa de reconhecimento, Cipião cercou Útica, que constituía uma excelente base e que dispunha de um porto. O assédio foi vagaroso e ocupou o inverno de 204-203 a.C., sendo a operação observada à distância por Asdrúbal Gisgão e por Sífax, acampados a uma dúzia de quilómetros. Na primavera de 203 a.C., Cipião optou por atacar estes acampamentos durante a noite, conseguindo um sucesso expressivo, o que lhe permitiu um maior à-vontade na continuação do cerco a Útica (e também a realização de grandes saques de vestuário e de alimentos, que foram guardados em grandes celeiros, no acampamento romano).

Os Cartagineses, depois de alguma hesitação, decidiram então juntar as forças de Sífax às de Asdrúbal Gisgão (reforçado por tropas hispânicas), conseguindo reunir 30000 homens no acampamento das chamadas "Grandes Planícies". Decidido a cortar o mal pela raiz, Cipião partiu em busca dos adversários e derrotou-os em batalha campal (203 a. C.), recorrendo novamente a uma manobra original: os principes e os triarii (as tradicionais segunda e terceira linhas do triplex acies romano) saíram de trás dos hastati (a primeira linha, formada por combatentes mais jovens) e flanquearam o centro adversário, composto pelos fortes e fiáveis Celtiberos; beneficiando também da vantagem romana nas alas de cavalaria (onde o apoio númida era crucial), Cipião obteve nas Grandes Planícies uma vitória extremamente importante. Depois disso, devastou a região circundante, 
enquanto Gaio Lélio tratava de restaurar Masinissa no trono dos Massilos. Neste ambiente, muitos líbios mostraram interesse em render-se a Roma, e tudo isso animou Cipião a ameaçar diretamente a cidade de Cartago.

Foi nesta altura, ainda em 203 a. C., que Cartago, preparando a sua defesa, mandou Aníbal Barca sair de Itália e regressar ao Norte de África. Quinze anos após a épica travessia dos Alpes, Aníbal embarcou em Crotona (no Brútio, no sudeste de Itália) e regressou à sua terra. As expetativas não seriam as melhores, pois os Romanos tinham ganho vantagem em todas as frentes (Itália, Hispânia, Sicília, Macedónia) e ameaçavam agora, com um exército poderoso, o coração do Estado púnico!

Cipião começou por ocupar Tunes $(25 \mathrm{~km}$ a sudoeste de Cartago) e por proteger a esquadra romana em Útica. Depois, Lélio e Masinissa derrotaram Sífax em batalha. A tenaz apertava-se, e em finais de 203 a. C. Cartago optou por negociar a paz. Cipião fez uma série de exigências que os Cartagineses pareceram aceitar, talvez para ganhar algum tempo (as fontes aludem por vezes à "manha púnica"), tendo enviado uma embaixada a Roma para confirmar o tratado. O inverno de 203-202 a. C. correspondeu, pois, a um tempo de armistício, e foi justamente durante este período que se deu o regresso de Aníbal Barca - a grande e, talvez, a única esperança da velha cidade fenícia para derrotar Públio Cornélio Cipião...

Mais animada, logo na primavera seguinte (202 a. C.), Cartago apreendeu alguns cargueiros romanos carregados de cereais, que tinham dispersado devido aos ventos; Cipião exigiu a devolução dos navios, mas os Cartagineses recusaram: com Aníbal em casa, Cartago queria de novo a guerra! Neste clima, o senado, pressionado pelo povo e por alguns notáveis (como Quinto Cecílio Metelo), prolongou o imperium de Cipião; ao mesmo tempo, atribuiu ao recém-eleito cônsul Tibério Cláudio Nero a tarefa de o apoiar por mar. A grande e decisiva batalha entre Aníbal e Cipião, um verdadeiro duelo de titãs, tornara-se inevitável...

Aníbal era cada vez mais pressionado por Cartago para enfrentar Cipião. Tentou ganhar algum tempo e reforçar o seu exército com tropas númidas (2 000 cavaleiros, sob o comando de Tiqueu, um parente de Sífax), e depois avançou para Zama, situada cinco dias a oeste de Cartago. Alguns emissários púnicos foram enviados ao acampamento de Cipião (instalado a uns $6 \mathrm{~km}$ 
de distância), sendo bem acolhidos, tanto mais que as forças de Masinissa ainda não tinham chegado (o que terá induzido em erro os espiões púnicos). Aníbal e Cipião ter-se-ão mesmo encontrado pessoalmente, mas não chegaram a acordo e a batalha de Zama (202 a. C.) não pôde ser adiada.

Foi um combate quase sem preliminares, ao contrário do habitual, e os dispositivos táticos não parece terem sido muito distintos, muito embora os Romanos tenham organizado uns corredores para contrariar as investidas dos elefantes, enquanto Aníbal optou, quiçá pela primeira vez, pelo uso de reservas, à maneira romana. Muito mais fracos em cavalaria (ao contrário do que sucedera em Canas), os Púnicos apostavam em romper ao centro, depois de os elefantes fazerem estragos na primeira linha romana; assim - acreditava Aníbal -, Cipião seria obrigado a gastar os hastati e os principes relativamente cedo, sendo o final da contenda travado entre os triarii (a terceira linha, menos numerosa e mais velha, dos Romanos) e os portentosos veteranos de Aníbal. Tal parece ter sido o plano de batalha cartaginês para criar embaraços ao exército de Cipião, mais coeso e mais bem treinado - visto que Aníbal pouco tempo tivera para adestrar o seu exército, grande parte do qual fora recrutado em África.

Em Zama, os elefantes atacaram antes do tempo, julga-se que devido ao ruído, e os flancos da cavalaria púnica tiveram uma prestação bastante pobre. Ao centro, a contenda entre as duas infantarias pesadas foi muito mais equilibrada, mas a segunda linha púnica, composta por Líbios e por Cartagineses, parece ter ajudado pouco (ao contrário da segunda linha romana, a dos principes, que injetou seiva nova na altura ideal). Na fase final da batalha, Aníbal foi obrigado a travar os seus veteranos, pois os cadáveres e o sangue que inundavam o terreno provocavam um risco elevado de as tropas escorregarem. Enquanto isso, Cipião alargou a sua frente, colocando os hastati e os principes nos flancos dos triarii, para evitar ser envolvido pela larga frente púnica. Deu-se então o choque dos núcleos duros dos dois exércitos, tendo a peleja, bastante equilibrada, acabado por ser decidida quando a cavalaria de Cipião, que perseguira os seus adversários em debandada, regressou ao campo de batalha, envolveu o exército de Aníbal por trás e perpetrou uma chacina com sabor a vingança, catorze anos depois de Canas... 
Na sequência da sua primeira derrota em batalha campal, Aníbal fugiu para Adrumeto (na costa leste), enquanto Lélio levava a Roma a boa nova. A seguir, guardados os prisioneiros e concretizadas as pilhagens da praxe, Cipião reforçou o abastecimento do seu arraial (o local ficaria conhecido por castra Cornelia) e protagonizou uma manifestação de força naval em frente de Cartago, cidade que não quis cercar, pois preferia a celebração da paz antes da sua substituição.

Desalentada, Cartago aceitou um novo tratado de paz leonino: os prisioneiros e os desertores romanos foram entregues sem qualquer resgate; os elefantes de guerra foram confiscados; a armada púnica foi limitada a dez barcos de "três"; Cartago perdeu todas as suas possessões ultramarinas e reconheceu Masinissa como rei de um território alargado; estipulou-se uma indemnização de 10000 talentos de prata, a pagar anualmente e durante 50 anos; Cartago foi proibida de fazer a guerra, dentro ou fora de África, sem a autorização de Roma; os vencidos teriam ainda de alimentar a hoste de Cipião durante três meses e de pagar o respetivo soldo até à ratificação do tratado; e haveria ainda lugar a uma compensação pelo desvio dos cargueiros romanos. Como garantia deste humilhante tratado, Cartago entregou uma série de reféns nobres.

Sem alternativa (como lembrou Aníbal aos seus conterrâneos), Cartago sujeitou-se a este acordo, que o senado romano ratificaria na primavera de 201 a. C. A vitória de Cipião fora total, justificando a celebração espetacular de um triunfo em Roma e, claro está, o cognome por que o herói ficou doravante conhecido: "o Africano".

Terminava assim a Segunda Guerra Púnica (218-201 a. C.), uma guerra muito mais intensa, variada e equilibrada do que a anterior, e durante a qual esteve em disputa não apenas o domínio de um território específico, mas a supremacia de uma das duas potências rivais. Com esta vitória, a posição dominadora de Roma no Mediterrâneo consolidou-se, o que permitiu à cidade do Lácio começar a pensar noutras aventuras.

Quanto a Aníbal Barca, manteve-se ainda durante alguns anos em Cartago, tendo chegado a ser eleito como sufeta, em 196 a. C. Porém, acusado pelos seus adversários políticos de conspirar com Antíoco III, rei da Síria, contra os interesses de Roma, e denunciado por esses inimigos 
ao senado, foi obrigado a fugir e a exilar-se, em 195 a. C., na corte do rei sírio, vendo os seus bens confiscados e a sua casa destruída.

Aníbal deve ter permanecido ao serviço de Antíoco III durante a "Guerra Síria" de 192-189 a. C., tendo comandado uma esquadra, que foi derrotada pelos Romanos em 190 a. C. Depois, quando Roma venceu mais esta guerra, Antíoco foi pressionado a entregar Aníbal aos seus adversários, que não esqueciam a tragédia de Canas; por isso, em 183 a. C., este teve de fugir para a Bitínia (na parte norte da Ásia Menor), sendo acolhido na corte de Prúsias; contudo, também ele pressionado por Roma para que entregasse o seu 'hóspede', mandou cercar a casa onde vivia Aníbal, que acabou por se suicidar com veneno, para que os Romanos não o apanhassem vivo. Assim terminava a saga de um dos maiores generais da história do mundo antigo.

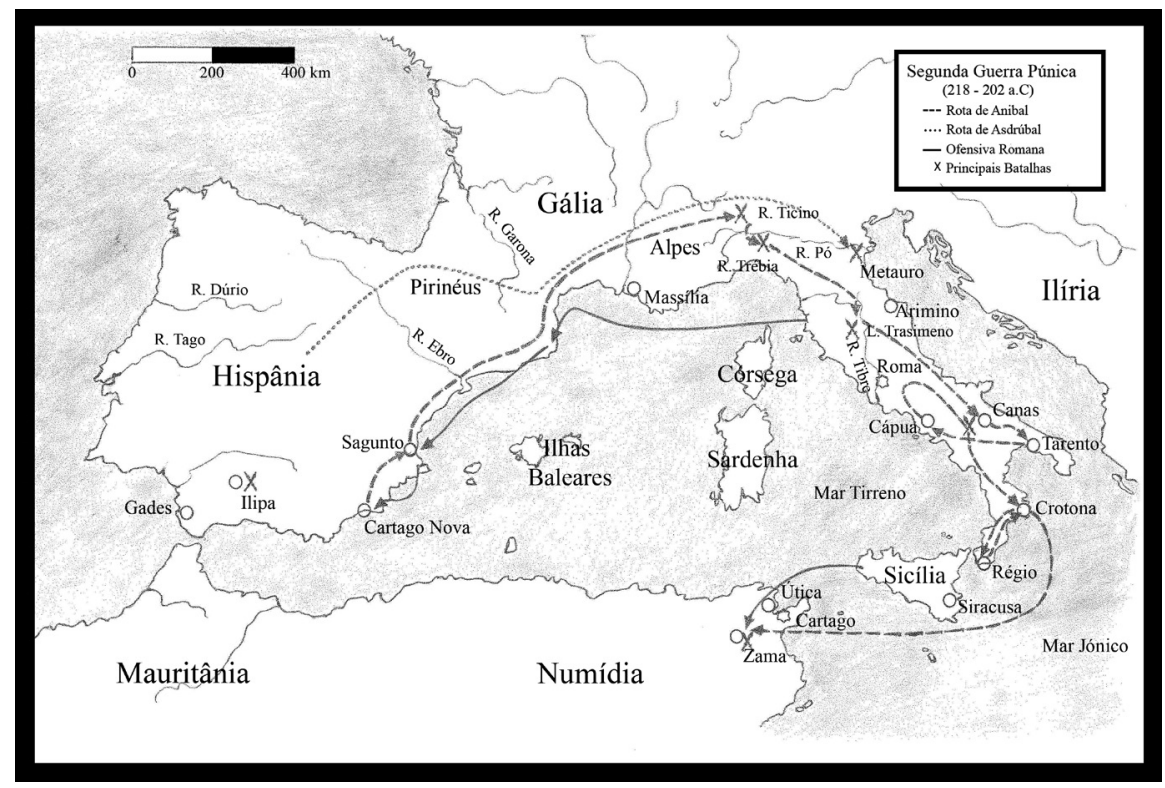

Fig. 2. $2^{\mathrm{a}}$ Guerra Púnica - por Fábio Mordomo

\section{A Terceira Guerra Púnica (149-146 a. C.)}

Ao contrário dos conflitos anteriores, a terceira guerra entre Roma e Cartago durou apenas três anos e circunscreveu-se a uma pequena região 
do Norte de África. A reconstituição deste último confronto permite perceber que Roma não se satisfizera com o duro tratado imposto em 201 a. C. e ambicionava a aniquilação da sua arquirrival.

Cartago cumprira com tudo aquilo a que fora obrigada após a vitória de Cipião "o Africano" sobre Aníbal Barca: fornecera cereais ao exército romano, enviara uma pequena frota contra Antíoco III, pagara todas as prestações da pesada indemnização e sujeitara à arbitragem de Roma os seus conflitos em África (designadamente contra os Massilos). Em 151 a. C., meio século depois do tratado de rendição, Cartago tinha liquidado a sua dívida de 10000 talentos de prata a Roma e voltara a prosperar. É possível que a velha urbe fenícia se tenha, entretanto, rearmado, mas nada que ameaçasse o poderio romano ou que fizesse prever uma nova guerra: Cartago era uma cidade de mercadores, que pensavam sobretudo na obtenção de lucros.

Mesmo assim, ao lermos os relatos de Apiano, percebe-se que Roma assistia inquieta ao renascimento cartaginês. Em 153 a. C., uma embaixada a Cartago, motivada pelo conflito entre esta cidade e o príncipe Masinissa, ficou impressionada com a prosperidade cartaginesa. Catão "o Antigo" (ou "o Censor"), personagem de referência da cultura romana, integrava essa embaixada e, a partir daí, passou a aconselhar sistematicamente, no final dos seus discursos, a destruição de Cartago: delenda Carthago... De acordo com Plutarco, Catão foi o mais influente dos notáveis de Roma na estratégia senatorial de aniquilar a cidade, mas seria, ao mesmo tempo, um fiel intérprete daquela que era já a vox populi.

Entre 153 a. C. e 151 a. C., Roma terá começado a pensar seriamente numa nova guerra púnica, e a decisão deverá ter sido tomada pouco depois. No entanto, era preciso um pretexto para iniciar a guerra, e a solução veio de Masinissa, o velho aliado númida. Em 152 ou 151 a. C., as autoridades de Cartago expulsaram da cidade os membros do partido pró-Masinissa, em reação ao facto de o rei númida - aproveitando a ambiguidade do tratado de 201 a. C. e o facto de contar quase sempre com uma arbitragem favorável de Roma - exigir cada vez mais território a Cartago. A cidade terá ficado dominada por um partido 'democrático', que exprimia sobretudo os interesses dos cidadãos pobres, sob a liderança de Aníbal "o Samnita" e de Cartalão. Os filhos de Masinissa (Gulussa e 
Micipsa) ainda foram enviados em embaixada a Cartago, mas a cidade não os deixou entrar e eles até foram atacados durante o seu regresso a casa.

Em 150 a. C., os Númidas retaliaram e devastaram o território cartaginês, pondo cerco à cidade de Oroscopa. Foi na sequência deste acontecimento que Cartago cometeu o erro que daria origem à Terceira Guerra Púnica: respondeu à agressão sem ter consultado Roma... Reunido um exército forte, sob o comando de Asdrúbal e de dois chefes númidas desertores (Asasis e Suba), os Púnicos venceram uma primeira escaramuça e perseguiram os adversários; esta manobra acabou por conduzir a uma batalha inconclusiva entre Masinissa e Asdrúbal. Por coincidência, nessa ocasião, estava no Norte de África um tribuno militar, que se vinha distinguindo na guerra na Hispânia, sob o comando do cônsul Lúcio Licínio Luculo: chamava-se Cipião Emiliano e era neto de Emílio Paulo (o cônsul romano abatido na batalha de Canas), tendo sido adotado por um filho de Cipião “o Africano”. O jovem tribuno era também 'parente' de Masinissa e estava em África para tentar obter do rei númida um pequeno corpo de elefantes, que pudessem ser úteis a Luculo na guerra contra os Celtiberos e os Lusitanos.

Assim, acabou por ser Cipião Emiliano a mediar as negociações entre Masinissa e Asdrúbal, mas a arbitragem não resultou, e o conflito prolongou-se. Encurralado no seu acampamento e sem possibilidade de obter reforços ou provisões, Asdrúbal acabaria por se render, e Cartago comprometeu-se ao pagamento de uma indemnização e a deixar regressar os aristocratas favoráveis a Masinissa que tinham sido expulsos da cidade.

Roma aproveitou este episódio e cavalgou a onda: o senado concluiu que Cartago violara o acordo de 201 a. C. e decidiu preparar uma invasão do Norte de África. Ao saber disto, Cartago (agora sob a influência do partido pró-romano liderado por Hanão "o Grande") procurou travar o processo: responsabilizou Asdrúbal, Cartalão e outros oficiais e enviou embaixadores a Roma; mas as respostas do senado foram enigmáticas: foi-lhes dito que Cartago devia "dar explicações" ao povo romano... Entretanto, a cidade de Útica aliou-se de novo a Roma, que em 149 a.C. achou estarem reunidas as condições para que o senado declarasse a guerra, obtida a aprovação dos Comitia Centuriata. Os dois cônsules 
do ano (Mânio Manílio e Lúcio Márcio Censorino) foram enviados para África, o primeiro com o exército terrestre, o outro à frente da esquadra; a concentração de forças deu-se em Lilibeu, na Sicília.

Alarmados, os Cartagineses enviaram uma outra embaixada a Roma, onde o senado lhes exigiu a entrega de 300 reféns nobres no espaço de 30 dias e lhes fez algumas promessas minimalistas, sem referir o que pretendia fazer com a cidade de Cartago. Já em Útica, num ambiente dramático, de parada militar, os dois cônsules receberam uma nova embaixada púnica; na ocasião, Lúcio Censorino exigiu aos emissários o desarmamento de Cartago, que aceitou a imposição e entregou 200000 armaduras de guerra, 2000 engenhos de torção e bastantes dardos e flechas, além de muitos projéteis de catapulta! Não contente, Censorino reclamou a evacuação de Cartago, declarando que a cidade seria arrasada (exceto os santuários e os cemitérios) e que era intenção de Roma erguer uma nova urbe, a um mínimo de $15 \mathrm{~km}$ do mar...

Claro que esta última exigência representava um golpe de tal forma violento para Cartago que, quando os embaixadores regressaram, o Conselho dos 104 rejeitou de pronto a pretensão romana. Em ambiente de fúria contra os simpatizantes de Roma e os seus aliados (muitos dos quais foram linchados, incluindo alguns mercadores itálicos), Cartago decidiu aceitar a guerra e tratou de improvisar um exército: foram libertados muitos escravos, outorgou-se o perdão a Asdrúbal e atribuiu-se o comando das tropas a um neto de Masinissa, também chamado Asdrúbal. Todos os cidadãos se empenharam na organização da defesa da capital, que os Romanos prometiam destruir.

Roma ficou surpreendida com a decisão cartaginesa: depois de tantas cedências e da entrega de uma imensa quantidade de armamento, não era expectável que a cidade quisesse lutar. Ainda assim, tudo parecia indicar que a campanha seria fácil. Mas não foi. Uma das explicações para a surpreendente resistência púnica tem que ver com a qualidade das defesas de Cartago: além de ser de aproximação difícil, a cidade dispunha de mais de $30 \mathrm{~km}$ de muralhas e de mais do que um porto. O istmo de ligação à cidade tinha 3 a $5 \mathrm{~km}$ de largura e estava protegido por uma linha tripla de defesas fortes, parcialmente assentes numa muralha com 
15 a $20 \mathrm{~m}$ de altura e $9 \mathrm{~m}$ de largura, antecedida de um fosso com $20 \mathrm{~m}$ de largo e de uma paliçada! No interior desta espessa muralha, tinham-se rasgado dois andares com acomodações para centenas de elefantes e cavalos e com alojamentos para milhares de peões e de cavaleiros. Em 149 a. C., Cartago não dispunha de animais de guerra, mas contou com a boa vontade de um elevado número de cidadãos e de populares, que se ofereceram para a guarnição da cidade. Desta feita, Cartago não travaria a guerra com um exército de mercenários...

Do lado romano, é provável que a força militar dos dois cônsules atingisse os números habituais: quatro legiões e outras tantas "alas" de auxiliares, num total de 40000 a 50000 efetivos. Em Roma, o entusiasmo era grande, pois antecipava-se uma conquista fácil e altamente lucrativa; no entanto, a verdade é que o exército de Manílio e de Censorino tinha escasso treino militar (a paz com Cartago adormecera a vitalidade militar da República), e a logística também parece ter sido um pouco negligenciada.

O primeiro ataque dos cônsules a Cartago deu-se em 149 a. C., por mar e por terra, sendo colocadas escadas nas muralhas e nos navios. Tendo fracassado, fez-se uma segunda tentativa, que foi igualmente mal sucedida. Os Romanos instalaram os seus acampamentos fortificados tradicionais, mas não evitaram que, durante uma operação de forragens nas redondezas, para obtenção de alimentos e lenha, Himilcão Fameias emboscasse 500 soldados, provocando uma primeira chacina. Uma terceira tentativa de assalto, de ambos os lados da cidade, também fracassou, posto o que Censorino ordenou a construção de dois aríetes e de um passadiço para os aproximar (o que implicou o enchimento de uma parte do lago de Tunes). As duas máquinas de 'marrar nos muros' conseguiram abrir dois buracos, mas os defensores repeliram os assaltantes e, durante a noite, tentaram colmatar as brechas; uma surtida noturna bem organizada acabaria, mais tarde, por anular os dois aríetes. Os Romanos ainda insistiram por uma das fendas, que permanecia por tapar: investiram com força, mas, por falta de organização, acabaram por falhar, tendo valido a intervenção do tribuno Cipião Emiliano para cobrir a retirada.

O cerco não estava a correr bem, e Censorino decidiu mudar o seu acampamento para um lugar mais a sul, com menos problemas de 
insalubridade. Nesta fase, os sitiados atacaram a esquadra romana com projéteis incendiários e realizaram algumas surtidas noturnas eficazes contra o acampamento de Manílio, posicionado na zona do istmo. Em resposta, o cônsul ergueu um forte junto à costa, para cobrir a aproximação dos navios que transportavam as provisões para o arraial dos sitiadores.

No inverno de 149-148 a. C., Censorino deslocou-se a Roma, e Manílio aproveitou para organizar uma expedição contra a área envolvente de Cartago, para intensificar a pressão e obter alimentos e lenha. Aí, de novo Himilcão Fameias aproveitou a inexperiência dos forrageadores e concretizou uma emboscada mortífera. Manílio decidiu então atacar o acampamento de Asdrúbal, que estava instalado perto da cidade de Neféris $(30 \mathrm{~km}$ a sudoeste de Tunes). A descrição de Apiano sugere que esta operação foi mal planeada, tendo Asdrúbal aproveitado o inevitável recuo romano para chacinar a força atacante, que na retirada ainda sofreu um novo ataque de Himilcão e, ao chegar ao seu acampamento, uma investida dos defensores de Cartago! O fiasco foi de tal ordem que o senado enviou uma comissão a Cartago para averiguar os pormenores da operação; o relatório elogiaria a prestação de Cipião Emiliano, que de novo terá evitado males maiores.

Em 148 a. C., morreu Masinissa, já com perto de 90 anos de idade. Na sua qualidade de descendente adotivo de Cipião "o Africano" (seu protetor e patrono), coube a Cipião Emiliano dispor dos seus assuntos, tendo o governo númida sido repartido pelos três filhos legítimos. Na ocasião, Cipião aproveitou para convencer Gulussa a juntar-se a Manílio, com uma força de cavalaria ligeira.

Na primavera de 148 a. C., desejoso de terminar com brilho o seu mandato consular, Manílio atacou novamente Neféris. Desta feita, a expedição foi bem preparada, mas ainda assim fracassou, com os Romanos a terem de retirar devido à fome. Valeu a deserção de Himilcão Fameias para o partido romano, conseguida por Cipião Emiliano e que mereceu ao desertor a atribuição de uma grata recompensa pelo senado.

Pouco depois, ocorreu a eleição dos novos cônsules; votou-se em Lúcio Calpúrnio Pisão Cesónio e Espúrio Postúmio Albino Magno, mas apenas o primeiro foi enviado para África, acompanhado pelo legado (ou propretor) Lúcio Mancino. Cartago permaneceu sob bloqueio (embora não 
muito cerrado), enquanto os Romanos tentavam subjugar outras cidades, como Áspis ou Hipagreta, tendo fracassado em ambos os casos.

Animados, os Cartagineses negociaram uma aliança com Andrisco da Macedónia (um rival de Perseu, o descendente de Filipe V), que já derrotara uma vez o exército romano. Nesta fase do conflito, Cartago beneficiou também da deserção de um dos chefes de Gulussa, acompanhado por uma força de 800 cavaleiros, tendo igualmente sido substituído o comandante de Cartago (linchado por planear uma traição com o filho de Masinissa) por um outro Asdrúbal.

Chegou-se então, no primeiro trimestre de 147 a. C., à fase crucial do conflito: os Comitia Centuriata elegeram como cônsul Cipião Emiliano, apesar de este não ter ainda idade para tal (tinha 36 ou 37 anos, menos cinco do que o mínimo exigido); de acordo com o relato de Apiano, a lei foi suspensa para permitir a exceção. Perante o interesse do outro magistrado eleito (Gaio Lívio Druso) em ser ele o cônsul enviado para África, o Concilium Plebis, por pressão de um tribuno, impôs a escolha de Cipião Emiliano para essa missão; o jovem cônsul foi também autorizado a recrutar e a levar consigo os voluntários que se apresentassem.

Quando Cipião Emiliano chegou a África, estava Lúcio Mancino (que ainda comandava a esquadra) a tentar uma escalada de Cartago a partir da praia. Os defensores haviam feito uma surtida, mas os Romanos tinham ido em sua perseguição e tinham conseguido penetrar na praça, tomando posse de uma pequena fração da cidade. A situação, porém, era muito precária, e Mancino enviou mensagens ao cônsul Pisão Cesónio e a Útica, onde Cipião Emiliano acabara de desembarcar. Compreende-se a aflição: os Cartagineses atacavam em força os Romanos, que tinham conseguido penetrar na cidade, e valeu a chegada de Cipião Emiliano e da sua esquadra para os salvar.

O novo cônsul tomou conta da situação e começou por restaurar a disciplina no seio do exército romano, procedendo a algumas expulsões. Depois, com Asdrúbal acampado a apenas um quilómetro, decidiu atacar Mégara, o grande subúrbio da cidadela de Cartago: foi feita uma incursão noturna, com dois comandos separados, tendo-se tomado uma torre e feito penetrar cerca de 4000 homens; os sitiados entraram em pânico e refugiaram-se na cidadela, mas Cipião Emiliano acabou por retirar, por prudência, devido 
à escuridão. A situação agravava-se para os Cartagineses, e deve ter sido nessa altura que Asdrúbal executou uma série de prisioneiros romanos no cimo dos muros, à vista de todos, com isso passando aos mais próximos uma mensagem clara - a de que já não haveria rendição possível. Perante os protestos de alguns membros do Conselho dos 104, o general mandou também executar alguns destes notáveis...

Cipião Emiliano tratou então de apertar o cerco à praça, tendo incendiado um acampamento adversário que havia sido abandonado e aproximando-se do istmo. Foram concretizadas, ao longo de três semanas, diversas obras de engenharia, tais como fossos, uma paliçada e diversas torres; porém, Cartago continuava a ser abastecida por mar, pelo que Cipião Emiliano mandou construir um molhe através do canal, assim controlando a estreita entrada dos navios nos grandes portos da cidade.

A resposta dos Cartagineses foi sublime: de noite e em sigilo, construíram um novo canal de ligação do porto militar ao mar e fabricaram uma nova esquadra, composta por 50 trirremes e por algumas embarcações mais ligeiras! Porém, não atacaram de imediato a desprevenida frota romana, uma vez que a tripulação cartaginesa carecia de uns dias de treino. Feito isso, deu-se uma batalha naval junto da costa. O combate foi renhido, pois os navios cartagineses eram mais pequenos e mais ágeis. Quando a superioridade romana se começou a manifestar, os barcos púnicos tentaram retirar, mas entupiram o acesso ao porto (o novo canal estaria, porventura, mal acabado, ou então houve alguma atrapalhação na manobra); por isso, as galés africanas refugiaram-se num cais junto às muralhas, com os esporões virados para fora. Era o momento de os navios romanos atacarem em força, mas sofriam muitas baixas na hora de recuar; a solução acabou por vir dos seus aliados de Side (na Ásia Menor, terra de excelentes marinheiros): os barcos passaram a lançar a âncora de popa antes de atacarem com o esporão, puxando depois à corda em vez de recuarem a remos, como até então. A vitória romana foi total, e os Cartagineses sofreram pesadas baixas, tendo as embarcações sobreviventes conseguido escapar para o porto quando a noite caiu.

Nesta altura, a vitória romana já era apenas uma questão de tempo. Cipião Emiliano continuou a atacar, a partir do molhe: os aríetes abriam 
brechas na muralha e a artilharia bombardeava de forma inclemente. Alguns cartagineses, nus, atravessavam o porto de noite, a nado, com tochas e com materiais para as acender, ateando depois muitos incêndios e lançando o pânico na zona dos engenhos romanos; ao mesmo tempo, os defensores iam tentando reparar os muros danificados e acrescentando torres de madeira, para arremesso de projéteis; os Romanos respondiam com novos engenhos e com rampas de assalto. Tomado o cais, Cipião Emiliano ordenou que erguessem um muro de tijolos em frente da muralha principal da cidade e com a mesma altura desta; o muro ficou pronto no início do outono de 147 a. C. e foi logo ocupado por 4000 homens, equipados com dardos e com muitos outros projéteis.

Para consolidar a posição romana em Cartago e evitar dissabores, Cipião Emiliano foi a Neféris e tomou o acampamento púnico e a cidade, recorrendo ao uso de reservas e a um ataque envolvente. Depois disto, à volta de Cartago, tudo se rendeu aos Romanos. Restava concretizar o assalto final, que aconteceu na primavera de 146 a. C., a partir do cais. Gaio Lélio (filho do legado principal de "o Africano") manobrou com destreza no porto interior, conseguindo uma infiltração. Já muito fragilizados e sem esperança, os sitiados viram os soldados romanos avançarem até à ágora (onde, para irritação de Cipião Emiliano, se detiveram a descascar o ouro que revestia o templo de Apolo). A seguir, os assaltantes avançaram por três ruas que ligavam a ágora à cidadela; muitos dos prédios tinham seis pisos e bons pátios centrais, e as vias, com cinco a sete metros de largo, apresentavam uma inclinação acentuada. Foi preciso tomar os edifícios quase um a um e suportar uma resistência inusitada, com uma chuva de projéteis arremessados dos telhados e das janelas dos prédios. Com esforço, os Romanos alcançaram a cidadela, mas precisavam de espaço para a instalação das máquinas; foi então improvisada uma rampa de assalto, com os escombros das casas, os cadáveres que jaziam nas ruas e até os corpos de alguns feridos a servirem de material de construção.

Finalmente, Cartago rendeu-se: uma delegação dos sitiados abandonou a cidadela munida de ramos de oliveira, o sinal convencional da capitulação. Cerca de 50000 pessoas (homens, mulheres e crianças) foram então enviadas para o cativeiro e a escravatura. Apenas prosseguiu a resistência 
dos que não tinham salvação possível: Asdrúbal e a sua família, mais os perto de 900 desertores romanos e itálicos. Muitos acabaram por se suicidar em grupo, no templo de Esculápio, incluindo a trágica esposa de Asdrúbal, depois de insultar o marido e de matar os seus próprios filhos.

Retido o ouro, a prata e as oferendas votivas, a cidade foi saqueada à discrição, tendo parte dos despojos sido objeto de repartição (Cipião Emiliano aproveitou para penalizar aqueles que tinham saqueado o templo de Apolo antes da hora). As armas e os navios cartagineses foram destruídos, e Roma comemorou efusivamente a sua terceira vitória sobre os Púnicos. A seguir, a cidade de Cartago foi arrasada por Cipião Emiliano, sob a supervisão do senado. O relato de Apiano mostra-nos Cipião chorando ao lado de Políbio, que presenciou quase todos os acontecimentos que evocámos e a quem se deve, com alta probabilidade, o retrato (excessivamente) generoso do herói desta conquista.

Cipião Emiliano celebraria mais tarde um aparatoso triunfo em Roma, tendo depois cumprido aí uma bem-sucedida carreira política: em 134 a. C., foi novamente eleito cônsul, tendo-se distinguido outra vez na Hispânia, na guerra contra os Celtiberos, durante a qual conquistaria a cidade de Numância (junto ao rio Douro), que mandaria também arrasar.

A Terceira Guerra Púnica trouxe o fim do Estado de Cartago, física e politicamente destruído, e a criação da província romana de África. O conflito foi muito mais breve, desequilibrado e circunscrito do que os anteriores, mas as suas consequências foram devastadoras: Roma triunfara em todas as frentes, Cartago não mais poderia erguer-se das cinzas.

\section{Comentário final}

As Guerras Púnicas tornaram Roma a força dominante no Mediterrâneo, a partir de 146 a. C. Nesta data, a cidade já dispunha de seis províncias ultramarinas - Sicília, Sardenha e Córsega, Hispânia Citerior, Hispânia Ulterior, África e Macedónia - e todas elas (com exceção da Macedónia) tinham sido criadas na sequência da guerra contra Cartago, que foi a sua última grande rival. 
Deste modo, as Guerras Púnicas aceleraram o imperialismo romano, habituando a cidade do Lácio a esforços de guerra prolongados e promovendo a adaptação do sistema político às novas circunstâncias - que exigiam a existência de mais pretores, a nomeação de mais governadores de província, uma avaliação mais rigorosa das necessidades terrestres e navais e uma diplomacia mais intensa, entre outros aspetos.

Roma habituou-se a manter soldados em teatros de operações cada vez mais distantes, e isso exigiu a canalização de recursos financeiros importantíssimos e uma intervenção cada vez maior do Estado em matéria logística. Ao mesmo tempo, foram as Guerras Púnicas que compeliram Roma a tornar-se uma potência naval: estima-se que, entre 260 e 241 a. C., tenham sido construídos perto de 1000 navios de guerra, na sua maioria "cincos", o que obrigou a um enorme investimento do Estado e até ao recurso ao empréstimo de particulares. Sem isso, a guerra na Sicília nunca teria sido ganha.

A vitória nas três guerras contra Cartago mostra também a tenacidade romana: mesmo quando tudo parecia perdido, como após a tragédia de Canas, o senado reagia, recusava negociar a paz e conseguia superar a situação! Para isso, foi preciso um esforço financeiro brutal, uma organização logística minuciosa e, claro, uma grande solidariedade entre as várias classes sociais, bem como uma fidelidade assinalável por parte dos aliados. A verdade é que ninguém levava a guerra tão a sério quanto os Romanos, e ninguém era tão implacável na forma de a executar - e, ao mesmo tempo, tão competente na maneira de absorver os povos conquistados.

Com a vitória final na guerra pelo domínio do Mediterrâneo, Roma ganhou consciência do seu enorme potencial e dos seus vastíssimos recursos financeiros e humanos (estes últimos, muito superiores aos de Cartago). Mas claro que as Guerras Púnicas (em especial a Segunda) também tiveram efeitos perversos: ao devastarem o território itálico e ao suscitarem exigências de mobilização militar inéditas, provocaram uma intensa psicose de guerra, causaram o empobrecimento e o declínio do pequeno campesinato, fomentaram o proletariado urbano e os latifúndios e contribuíram decisivamente para a criação de exércitos privados de generais, capazes de capitalizar aquelas forças armadas mais 'profissionais', que se constitu- 
íam para as grandes ocasiões e que, depois de desmobilizadas, ficavam à disposição dos notáveis, que as podiam remunerar em proveito próprio. A história dos graves conflitos internos do último século e meio da República romana - assunto de que se falará mais à frente - não é, certamente, estranha a tais desenvolvimentos...

\section{Tábua cronológica}

264-241 - Primeira Guerra Púnica, entre Roma e Cartago.

220-219 - cerco de Sagunto (Hispânia) por Aníbal Barca.

218-201 - Segunda Guerra Púnica.

218 - Batalhas de Ticino (novembro) e de Trébia (dezembro).

217 - Batalha do lago Trasimeno.

216 ( 2 de agosto) - Batalha de Canas.

202 - Batalha de Zama.

183 - Suicídio de Aníbal Barca, na Bitínia.

149-146 - Terceira Guerra Púnica (cerco e destruição de Cartago).

\section{Bibliografia}

\section{Fontes principais}

Apiano, História Romana ("Guerras Púnicas», caps. 10 a 20, 67 a 135). Utilizámos a tradução inglesa de Horace White: Appian, Roman History, Loeb Classical Library, 4 vols., 1912.

Políbio, Histórias (Livro III, 113-118). Utilizámos a tradução inglesa de Ian Scott-Kilvert: Polybius, The Rise of the Roman Empire, Penguin Books, 1979.

Tito Lívio, História de Roma (Livro XXII, 43-61). Utilizámos a tradução inglesa de Aubrey de Sélincourt: Livy, The War with Hannibal, Penguin Books, 1972.

\section{Leituras-base recomendadas}

Goldsworthy, Adrian (2009), A Queda de Cartago. As Guerras Púnicas, 265-146 a. C. Trad. port. (ed. orig.: 2000). 
Brizzi, Giovanni (2007), Moi Hannibal... Mémoires d'un conquérant hors du commun. Trad. franc. Paris, Les Éditions Maison (Ed. It. origin. 2003).

\section{Leituras complementares}

Goldsworthy, Adrian (2001), Cannae. Londres.

Brizzi, Giovanni (2008), Il guerriero, l'oplita, il legionario. Gli eserciti nel mondo classico. Bolonha, Il Mulino.

Brizzi, Giovanni (2010), Scipione e Annibale. La guerra per salvare Roma. Bari, Laterza.

Monteiro, João Gouveia (2012), Grandes Conflitos da História da Europa. De Alexandre Magno a Guilherme "o Conquistador". Coimbra 73-108.

Lazenby, J. (1978), Hannibal's War. Warminster.

Connolly, Peter (1989), "The Roman army in the age of Polybius" in Sir John Hackett, ed., Warfare in the Ancient World. Nova Iorque, Oxford, Sidney, Facts on File 149-168.

Cornell, T. - Rankov, B. - Sabin, Ph. (1996), The Second Punic War: A Reappraisal. Londres. 